\title{
Forced regressive wedge in the Mesoproterozoic Koldaha Shale, Vindhyan basin, Son Valley, central India
}

\author{
Pradip Samanta $^{1}$, Soumik Mukhopadhyay ${ }^{2}$, Patrick George Eriksson ${ }^{3}$ \\ ${ }^{1}$ Durgapur Government College, Durgapur - 713 214, West Bengal, India \\ 2 Jadavpur University, Kolkata - 700 032, West Bengal, India \\ Department of Geology, University of Pretoria, Pretoria 0002, South Africa \\ *Corresponding author's email: samanta.pradip@gmail.com \\ Tel: +919433116101
}

\begin{abstract}
The present paper highlights the sequence development within the Mesoproterozoic Koldaha Shale Member of the Kheinjua Formation, Vindhyan Supergroup which records the occurrence of a forced regressive wedge and associated discontinuity surfaces at the base of the wedge. Nine lithofacies have been identified within the study area that are grouped into three lithofacies associations varying in depositional setting from outer shelf, through shorefaceforeshore-beach to continental braidplain. The outer shelf sediments are aggradational to slightly progradational representing highstand systems tract. The rapidly progradational, wedge-shaped shoreface to foreshore-beach succession occurs sharply or erosively above the outer shelf sediments and is bounded by a regressive surface of marine erosion (RSME) at the base and by a subaerial unconformity at the top. This, along with its downstepping trajectory, supports deposition of this sedimentary wedge during falling sea level. A laterally extensive soft sediment deformation zone occurs at the base of the wedge.

The forced regressive wedge is incised by fluvial braidplain deposits that rest on an erosive surface representing a sequence boundary. The thin braidplain deposits are the product of aggradation during a subsequent early rise in relative sea level, and thus, they are inferred to represent a lowstand systems tract. The constituent architectural elements that characterize the braidplain deposits are downstream accretion elements and small channel elements. Further
\end{abstract}


landward, the base and top of the shoreface wedge merge to form an unconformity across deposits that rest directly on the outer shelf sediments. The identification of forced regressive wedges has significant economic importance in view of the potential occurrence of hydrocarbons within the Proterozoic formations.

Keywords: Koldaha Shale, Mesoproterozoic, Vindhyan Supergroup, Forced regression, Regressive surface of marine erosion (RSME), Microbial mat.

\section{INTRODUCTION}

Forced regression can be defined as shoreline advance under dominance of fall in relative sea-level (Hunt and Tucker, 1992; Posamentier et al., 1992; Ainsworth and Pattison, 1994; Posamentier and Morris, 2000). Over the past two to three decades, studies carried out on active and passive margins demonstrated that the deposits of the continental shelves mostly consist of lowstand and transgressive systems tract deposits (Suter and Berryhill, 1985; Suter et al., 1987; Tesson et al., 1990, 1993; Saito, 1991; Okamura and Blum, 1993; Trincardi and Correggiari, 2000). It is argued that highstand deposits are rarely preserved on outer shelves; they commonly occur on the inner part of the basins and form thick wedges thinning significantly basinwards. Moreover, the preservation of highstand deposits is often difficult in the outer shelf, possibly due to the erosive action of waves and currents (Aiello and Budillon, 2004). Evidently, dominance of relative sea-level falls on the inner shelf, subsequent to phases of rising, are more prominent and often cause partial erosion of highstand deposits, along with sediment reworking in the coastal areas (Field and Trincardi, 1992; Gensous et al., 1993). Nevertheless, the large-scale stratigraphic architecture of forced regressive deposits has been addressed in many previous studies (e.g., Posamentier et al., 1992; Posamentier and Allen, 1999; Posamentier and Morris, 2000). Moreover, evidence of outer shelf forced regressive deposits is not rare, and a variety of forced-regression deposits has been documented from the Plio-Quaternary settings (Trincardi and Field, 1991; Ercilla et al., 1994; Sydow and Roberts, 1994, Morton and Suter, 1996; Gensous and Tesson, 1996; Somoza et al., 1997; Chiocci et al., 1997; Naish and Kamp, 1997; Berné et al., 1998; Massari et al., 1999; Rodero et al., 1999; Haywick, 2000; Chiocci, 2000; Pomar and Tropeano, 2001; Berné et al., 2002; Amorosi et al., 2004; Cantalamessa and Di 
Celma, 2004; Cantalamessa et al., 2006). Despite the vulnerability of the forced regressive deposits to erosion during sea level fall and subsequent early rise (Posamentier and Morris, 2000), in recent years, considerable work has been carried out on forced regressive deposits due to their potential for hydrocarbon reservoirs (Posamentier et al., 1992; Plint and Nummedal, 2000; Posamentier and Morris, 2000; Hunt and Gawthorpe, 2000; Lee et al., 2007; Zecchin and Catuneanu, 2015). The relatively thin and detached occurrence of these sand bodies may be the reason for their limited identification and description in the literature (Plint, 1988; Proust et al., 2001). The small thickness of these forced regressive wedges is possibly related to the limited availability of time for their deposition, marked foreshortening during forced regression, and transgressive ravinement processes (Zecchin et al., 2011; Catuneanu and Zecchin, 2013). Thick and extensive forced-regression deposits include a significant amount of fine-grained material and form multi-storey progradational/regressive sequences in many Quaternary margins, reflecting the periodicity of climate-driven sea level cycles (Ridente and Trincardi, 2005). Highresolution seismic analysis is useful in understanding the forced regressive deposits; such analysis in the Quaternary shelf-edge deltas of the Gulf of Lions and the Gulf of Mexico, provides insights into the stratigraphic organization of forced regressive deposits (Hart and Long, 1996; Tesson et al., 2000; Anderson and Fillon, 2004; Serge and Gorini, 2005; Gwenael et al., 2006).

The studies on the forced regressive deposits are mostly confined to Phanerozoic formations. Only a few examples are focused on Precambrian settings (cf. Chakraborty and Paul, 2008). Despite the paucity of examples in the literature it is pertinent to note that the slow subsidence and low-gradients inferred for many Proterozoic epeiric basins (Bose et al., 2001; Sarkar et al., 2001, 2008; Taylor et al., 2001; Eriksson et al., 2002, 2008) make them ideal situations for understanding the response of falling stage systems tracts in such basins. In other words, the Proterozoic formations were more significant in forming falling-stage systems tracts. High-resolution sequence stratigraphic observations and modeling are limited in the Precambrian basin-fills, and have been attempted mostly on low resolution 'layer cake' lithostratigraphy at different scales of observation (Christe-Blick et al., 1995; Catuneanu and Eriksson, 1999). Thus it is necessary to revisit the shallow marine epeiric deposits, and also those on the preserved outer shelf settings of these basins to understand the high resolution sequence architecture of these basin-fills in time and space. 
The present paper uses depositional facies, facies associations and transitions of facies associations for understanding palaeoenvironments and their shift with time and space. Correlation of palaeoenvironments has been made by using field evidence of major erosion surfaces (unconformities) and other correlative surfaces to build-up sequence architecture for understanding a Meoproterozoic forced regressive deposit in the Koldaha Shale Member, Vindhyan Supergroup, central India. The outcrop-based study aims at identifying depositional discontinuities/unconformities through high resolution sequence analysis, characterizing the highstand, forced regressive and lowstand products (rising stage, falling stage and subsequent early rise), and documentation of sequence architecture of the marine and terrestrial deposits in the Koldaha Shale Member. Documentation of outcropping shelf-edge sand bodies ideally requires continuous lateral exposures from terrestrial basin margin, across the shelf to palaeoshelf edge, and further exposure also of slope to basin deposits, which are only rarely available (Surlyk and Noe-Nygaard, 2005). The present study investigates a fortuitous long continuous outcrop of the Koldaha Shale and allows us to understand the stratigraphic architecture of the Koldaha Shale that records a falling stage systems tract in this Mesoproterozoic formation. In the study area the Koldaha Shale can be subdivided into two major intervals: marine and terrestrial. The marine interval can further be subdivided into an entirely muddy unit of offshore origin below and a dominantly sandy wedge of shallow marine origin above (Fig. 1). A terrestrial interval of dominantly fluvial origin unconformably overlies this shallow marine interval. The transition of the argillaceous to arenaceous intervals shows that the change is sharp and erosional in the present study area. Three depositional sequences have been established that record highstand, falling stage and lowstand systems tract in the Mesoproterozoic Koldaha basin.

\section{GEOLOGICAL BACKGROUND}

The Vindhyan Supergroup in central India (Fig. 1), ranging in age from Palaeo- to Neoproterozoic, is dominantly composed of siliciclastic and carbonate sedimentary rocks. The entire Vindhyan Supergroup is only mildly deformed (Bose et al., 2001) and covers an area of $104,000 \mathrm{~km}^{2}$. The Supergroup is roughly $4.5 \mathrm{~km}$ thick and divided into two parts, the lower

Vindhyan, also known as the Semri Group, and the upper Vindhyan, separated by an unconformity laterally passing into a conformity surface (Fig. 1). The lower Vindhyan 


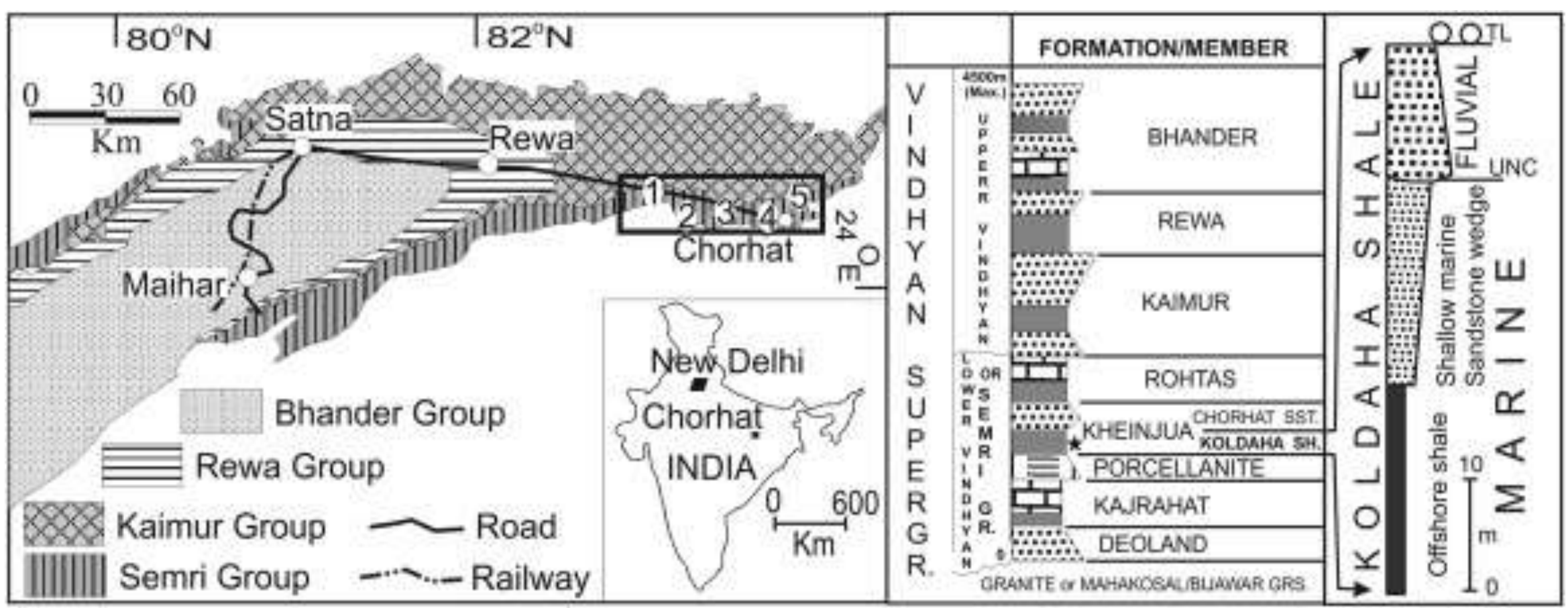

Fig. 1. Geological background of the study area: location and geological map showing distribution of the Semri Group (Lower Vindhyan) and associated younger formations. Note the study area has been marked by the rectangular area. Numbers indicate the litholog locations used in Figs. 15 and 16 (left). The relevant stratigraphic column and subdivisions of the Kheinjua Formation are shown on the right. The inferred subdivisions into marine and fluvial units of the Koldaha Shale and their palaeoenvironmental ranges have also been shown. Note that the stratigraphic age of the dated rock has been marked with an asterisk. Map of India within inset. UNC $=$ unconformity and TL $=$ transgressive lag. 
sedimentation commenced in an intracratonic rift setting that later transformed into a sag basin during upper Vindhyan time (Bose et al., 2001). The Semri Group outcrops in a fairly continuous exposure along the southern limb of a westerly plunging broad syncline in and around the valley of the Son River, whereas the exposures are discontinuous on the northern limb (Fig. 1).

Within the Semri Group, the Kheinjua Formation is divisible into two Members, the Koldaha Shale and the Chorhat Sandstone (Fig. 1), in a sedimentation continuum (Bose et al., 2001). The Koldaha Shale has a gradational contact with the underlying Porcellanite Formation and also conformably passes into the overlying Chorhat Sandstone (Bose et al., 2001; Banerjee and Jeevankumar, 2005). The interpreted palaeoenvironment of the Koldaha Shale is dominantly offshore (Banerjee, 2000) while the Chorhat Sandstone is seen as shallow marine, ranging in palaeogeography from subtidal to supratidal-erg margin through an intertidal setting (Sarkar et al., 2006). The Kheinjua Formation is dated as $1.63-1.60 \mathrm{Ga}$ on the basis of U/Pb SHRIMP dating of zircon grains in the tuffaceous layers bounding the Formation immediately below and above (Rasmussen et al., 2002). A relatively younger age of $1205 \pm 233.6$ Ma has been assigned to the Koldaha Shale by the fission track (F-T) dating method (Srivastava and Rajagopalan, 1988). Detailed review of recent literature indicates that the age of the Koldaha Shale can be assigned as Mesoproterozoic (Sarkar et al., 1995, 1996, 2002a; Ray et al., 2002: Schieber et al., 2007 and references therein).

Excellent exposures of the Koldaha Shale occur in and around the Chorhat area, on either side of the Son River, upon which this study is, based (Fig. 1). A comprehensive palaeogeographic analysis including temporal variations has been carried out by Bose et al. (2001) in a study that also provided a general outline of sequence stratigraphic architecture of the Semri basin in central India. Despite these broad palaeoenvironmental interpretations (Bose et al., 2001), in-depth sedimentological analysis of the Vindhyan Supergroup has been initiated only lately. This paper utilizes the spectacular preservation of sedimentary structures and lithologies of both terrestrial and marine segments of the Mesoproterozoic Koldaha Shale Member to reconstruct the depositional mileu in detail, and to use the inferred palaeogeography and its temporal variations to provide a detailed sequence stratigraphic framework for the Member. 


\section{FACIES ANALYSIS}

The succession in the study area can be subdivided into three units on the basis of lithology. Three distinct lithological assemblages are found, and occur in vertical succession with sharp contact to each other. The basal litho-assemblage consists of shale with occasional siltstone layers and a massive ash bed. The middle assemblage consists mostly of sandstone with subordinate shale and/or siltstone. The shale and the overlying sandstone (lower and medial litho-assemblages) together constitute the marine assemblage of the Koldaha Shale (Fig. 1). The upper litho-assemblage is composed of relatively coarse-grained, poorly sorted sandstone that has incised into the middle, and even the lower litho-assemblage.

These three litho-assemblages essentially correspond to three facies associations across the marine-fluvial succession of the Koldaha Shale, with distinct depositional environments inferred from facies characterized by specific lithologies and primary sedimentary structures.

\subsection{Facies Association I:}

This facies association constitutes the basal litho-succession, with little variation in character and is exposed all along the study area. The thickness of the facies association varies laterally, ranging from $20 \mathrm{~m}$ to $6.8 \mathrm{~m}$. This facies association is well exposed along the Son river-cut section, and is divided into four facies.

\subsubsection{Facies A: Black shale}

Description: This facies is dark greenish to black in colour, comprised mainly of shale with well-developed fissile planes and locally contains laterally extensive silt stringers (Fig. 2a). The thickness of these silt layers is centimetric in scale and they are internally massive. Maximum thickness of this facies is $\sim 20 \mathrm{~m}$. The shale is pyrite-bearing (Bose et al., 2001). The silt stringers have sharp lower contacts and gradational upper contacts with the shale. Clastic sediment microbial mat features like wrinkles (small scale crinkles on bed surfaces; Schieber et al., 2007) are present abundantly on the bed surfaces of both shale and silt laminae (Fig. 2b). 

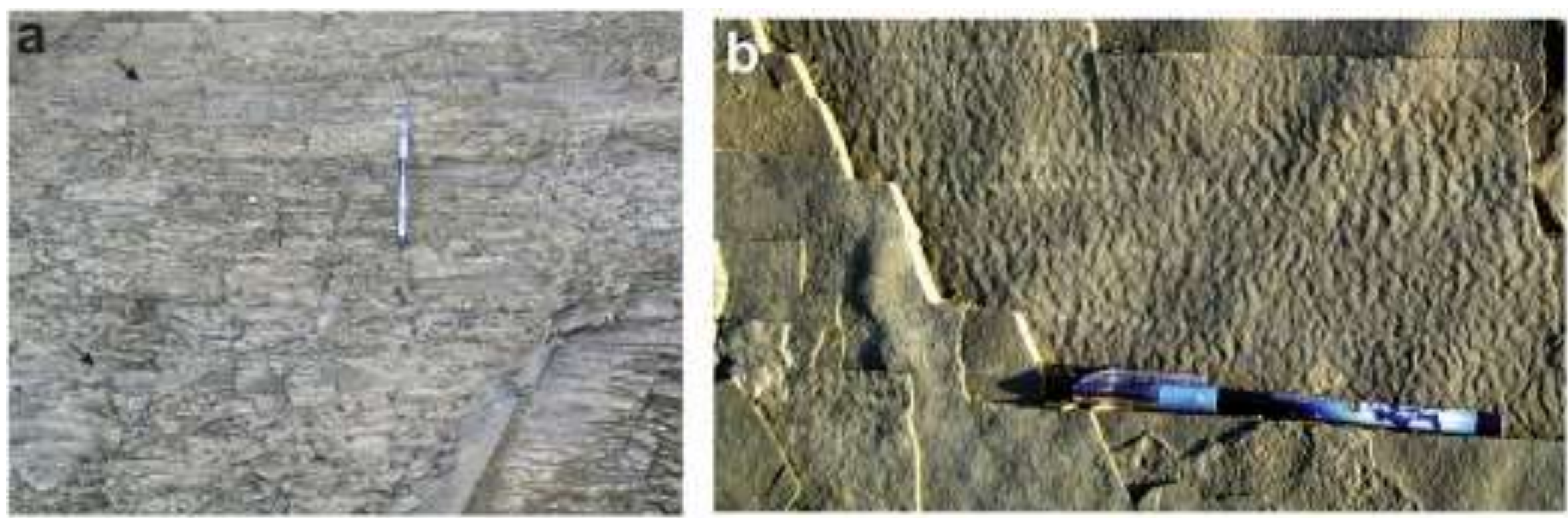

Fig. 2. Dark coloured shale with well-developed fissile planes within facies A. Note occurrence of laterally extensive massive siltstone stringers (arrows). Pen length $14 \mathrm{~cm}$ (a). Wrinkle marks of microbial mat origin within the siltstone of facies A. Pen length $15 \mathrm{~cm}$ (b). 

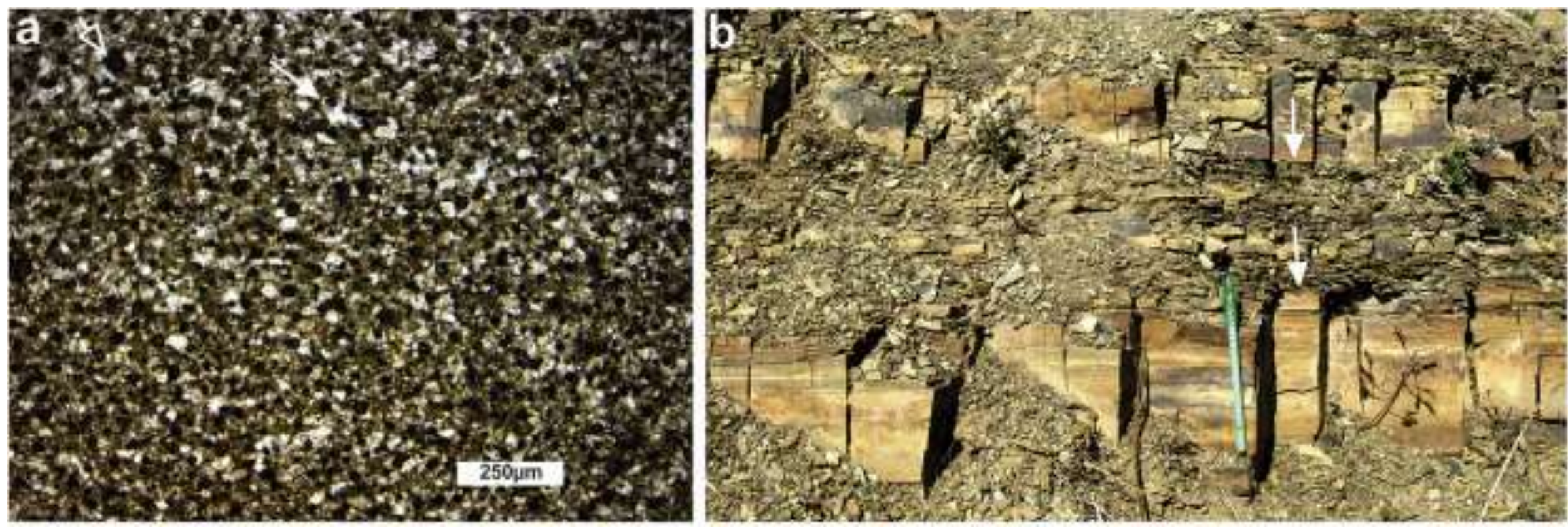

Fig. 3. Photomicrograph under crossed polars of facies $\mathrm{C}$ composed of microcrystalline quartz grains. Note occurrence of larger grains (solid arrow) and glassy materials (open arrow) (a). Facies B alternating with siltstone-mudstone of facies A. Note both the upper and lower contacts are sharp (arrows). Pen length $15 \mathrm{~cm}(\mathrm{~b})$. 


\subsubsection{Facies B: Porcellanite/Ash bed}

Description: This facies is grey to fleshy coloured, consists of very fine-grained microcrystalline quartz with occasional bombs and blocks (Fig. 3a; Bose et al., 2001). It is interbedded with facies $\mathrm{A}$ and $\mathrm{C}$ (described below) in variable proportions (Fig. 3b) and thus the resulting thickness varies. Commonly the ash beds are amalgamated to form large thicknesses (maximum measured thickness $5.8 \mathrm{~m}$ ) of porcellanite in certain parts of the study area. Quenching cracks and pumice are also frequently present (Bose et al., 2001). Both the lower and upper contacts of this facies with facies $\mathrm{A}$ and $\mathrm{C}$ are sharp (Fig. 3b).

\subsubsection{Facies C: Black to grey shale interbedded with siltstone and fine sandstone}

Description: This facies gradationally overlies facies A and varies in lithology laterally. The thickness and the character of the shale vary laterally as well as vertically. The shale layers are also organic-rich. The shale changes colour, becoming greyish from black towards the top and is interbedded with siltstone and fine sandstone (Fig. 4). The siltstone/fine sandstone layers are internally massive or sometimes planar laminated (Fig. 4). The silt : shale ratio is relatively greater than that of facies A.

\subsubsection{Facies D: Grey shale and siltstone interbedded with lenticular medium sandstone}

Description: This facies gradationally overlies facies A and/or C and is composed of grey shale and siltstone alternations (Fig. 5a). The thickness of this shale-siltstone alternation varies from 5 $\mathrm{cm}$ to $30 \mathrm{~cm}$. The colour of the shale is grey indicating low carbon content and the sand : shale ratio is more than that observed in facies $\mathrm{A}$ and $\mathrm{C}$. The sand bodies are lenticular and internally graded at the base followed by current ripple laminated sandstone above (Fig. 5b). The thickness of the sandstone beds varies from a few centimetres up to $1.2 \mathrm{~m}$. The basal contacts of the sandstone bodies are sharp, locally erosional, and their gradational upper contacts are often indistinct. 


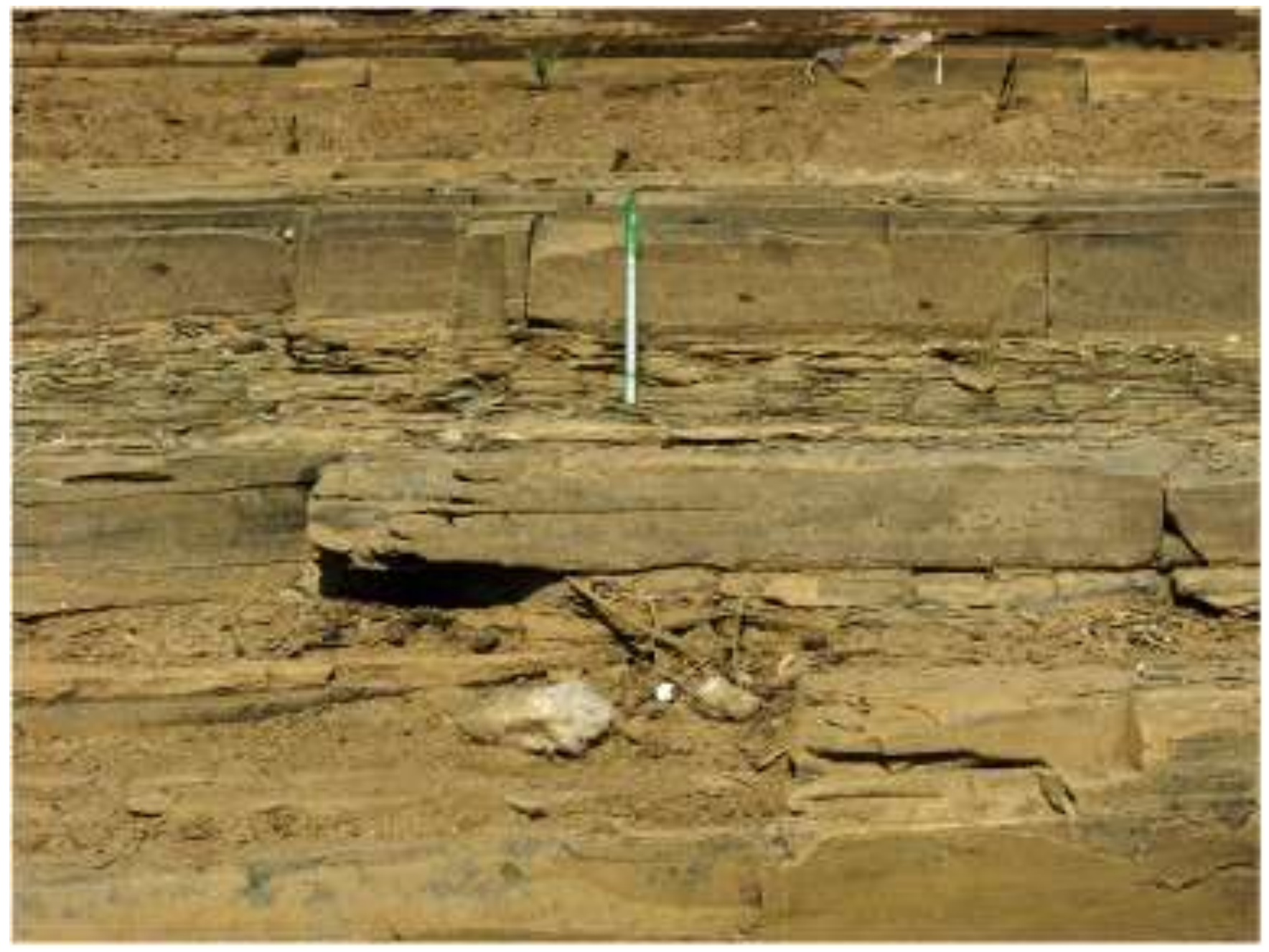

Fig. 4. Greyish shale alternating with planar laminated siltstone and fine sandstone within facies C. Note the shale : silt ratio is greater than for facies A. Pen length $15 \mathrm{~cm}$. 

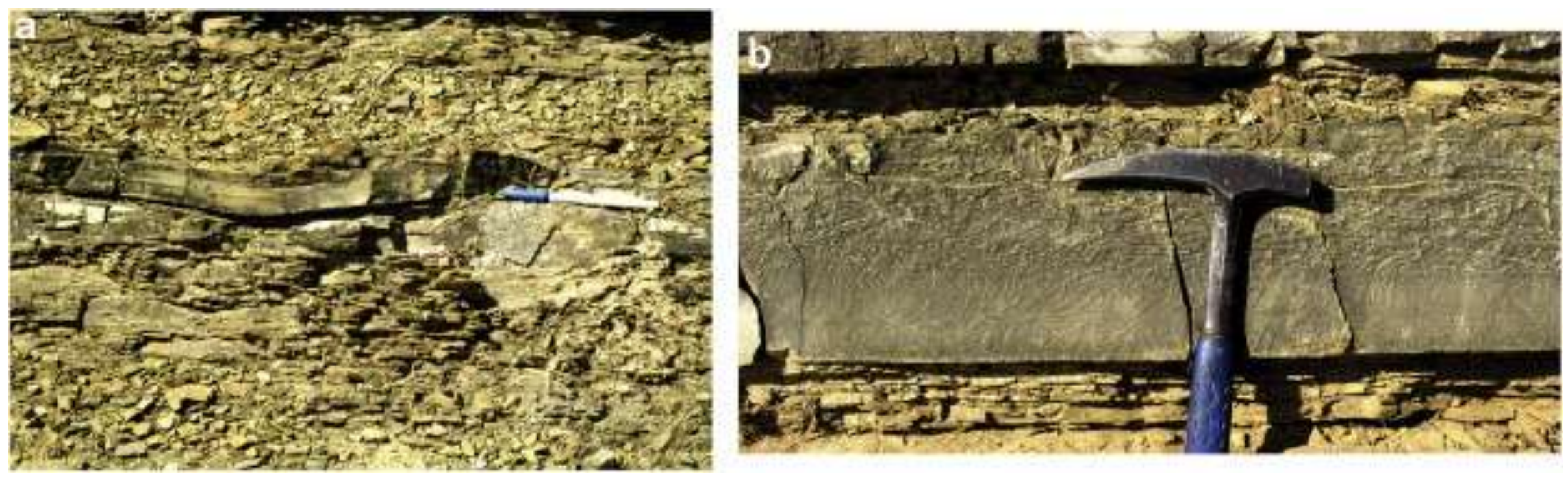

Fig. 5. Shale - siltstone alternations with lenticular sandstone beds interspersed with the heterolithic units within facies D. Pen length $15 \mathrm{~cm}$ (a). The sandstone body is massive at the base followed by ripple laminae towards the top. Note the sharp basal contact and gradational upper contact of the sandstone unit. Hammer head $8 \mathrm{~cm}(\mathrm{~b})$. 


\subsubsection{Interpretation}

From the grain size and lack of identifiable wave/current or emergence features within facies A, it is suggested that the facies was deposited in the oxygen deficient outer shelf setting below storm wave base (cf., Davis et al., 1989). The occasional silt stringers are interpreted as the product of relatively high energy events, such as major storms (cf., Sarkar et al., 2002b; Chakraborty and Sarkar, 2005). The wrinkles are thought to have been the product of emission of gas bubbles from beneath the decomposing mats (Sarkar et al., 2006, 2008). Facies B is seen as the product of syn-depositional volcanic ash laid down with the shale facies (Bose et al., 2001). Logically, this facies has no relation with the depositional environment of Facies $\mathrm{A}$ or $\mathrm{C}$ as it is of a volcanic ash origin and should temporally and spatially be distributed all through the depositional surfaces covering all palaeogeographic regions during that time. The depositional condition of facies $\mathrm{C}$ is still oxygen-deficient low energy conditions similar to that of facies $\mathrm{A}$ as evident from lack of emergence features and colour of the constituent shale (cf., Olszewski and Patzkowsky, 2003). The lack of any current/wave structures clearly points to its origin below storm wave base. The interbedded siltstone laminae are interpreted as the product of occasional strong high energy events, such as major storms (Sarkar et al., 2002b; Chakraborty and Sarkar, 2005). The increase in silt : shale ratio suggests relatively shallower condition of deposition of facies $\mathrm{C}$ but still within the outer shelf and below storm wave base. The internal structures and association with the other three facies suggest that the facies D formed in the outer shelf, below storm wave base as no fair-weather wave features are found. The lenticular sandstone bodies probably represent turbidity current generated flows due to slope instability or may be the product of liquefaction of storm derived materials upslope (cf., Walker, 1984; Pattison, 2005). Facies D is inferred to have been of relatively shallower depth than facies A and C. Thus this facies association altogether represents an outer shelf depositional setting with gradual shallowing of the depositional condition and the transition from facies $\mathrm{A}$ to $\mathrm{D}$ through $\mathrm{C}$ is aggradational to slightly progradational (Fig. 6).

\subsection{Facies Association II:}

This facies association is predominantly sandy in its lithology. The facies association is progradational within itself as well as in it being stacked above facies association I. Laterally 


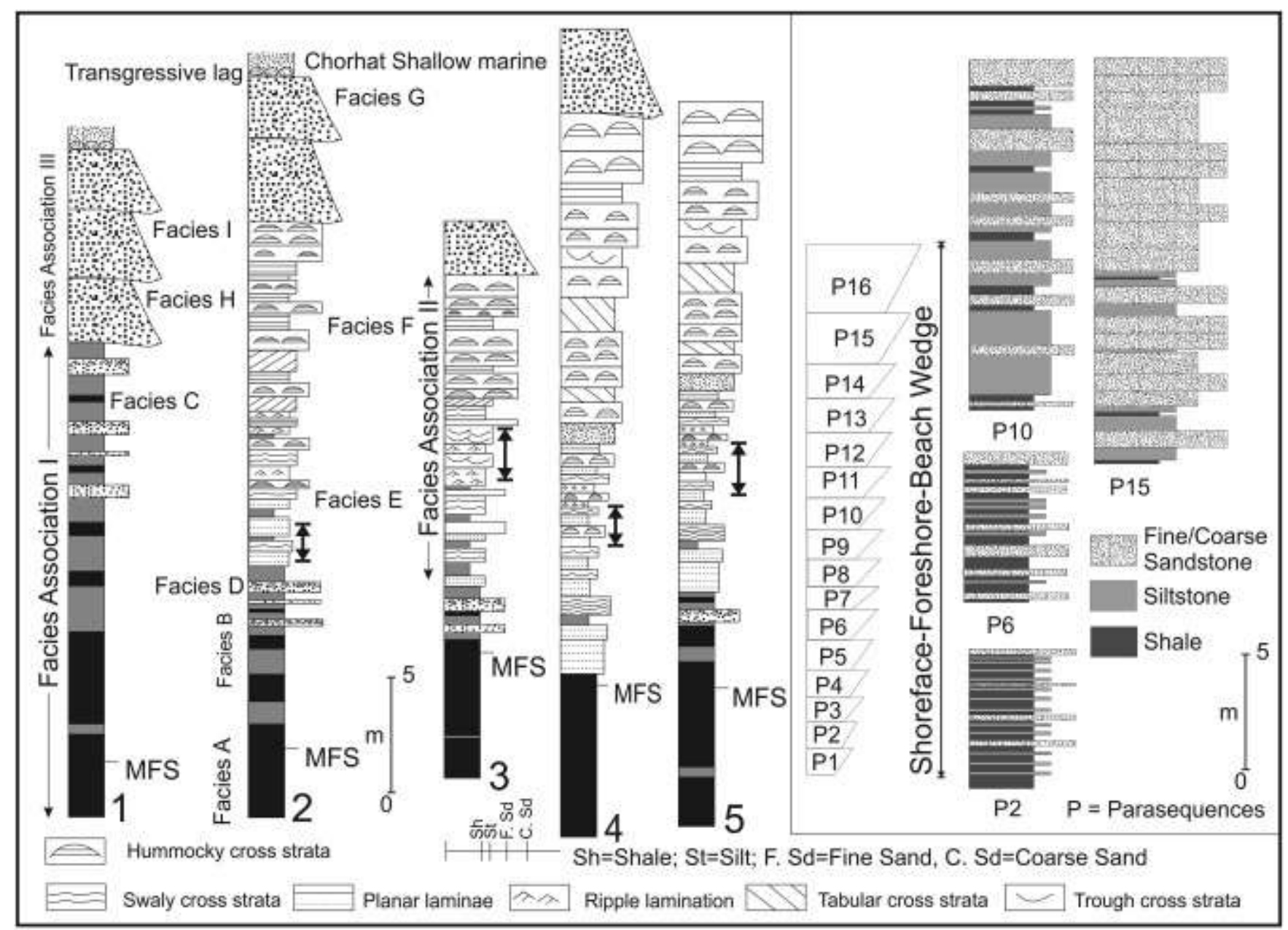

Fig. 6. Litho-successions showing distribution of lithofacies within each facies association of the Koldaha Shale constructed at different locations of the study area, shown in Fig. 1. Note that the facies association I is aggradational to slightly progradational as silt : shale increasing upward. Composite parasequences within the forced regressive wedge (facies association II) have also been shown on the right. The grain-size and facies transitions clearly show thickening and shallowing upward trend suggesting progradation within both the facies associations I and II. Note the double-arrowed markings at the basal part of facies association II in the lithologs represent occurrence and range of distribution of soft sediment deformation structures for each succession. 

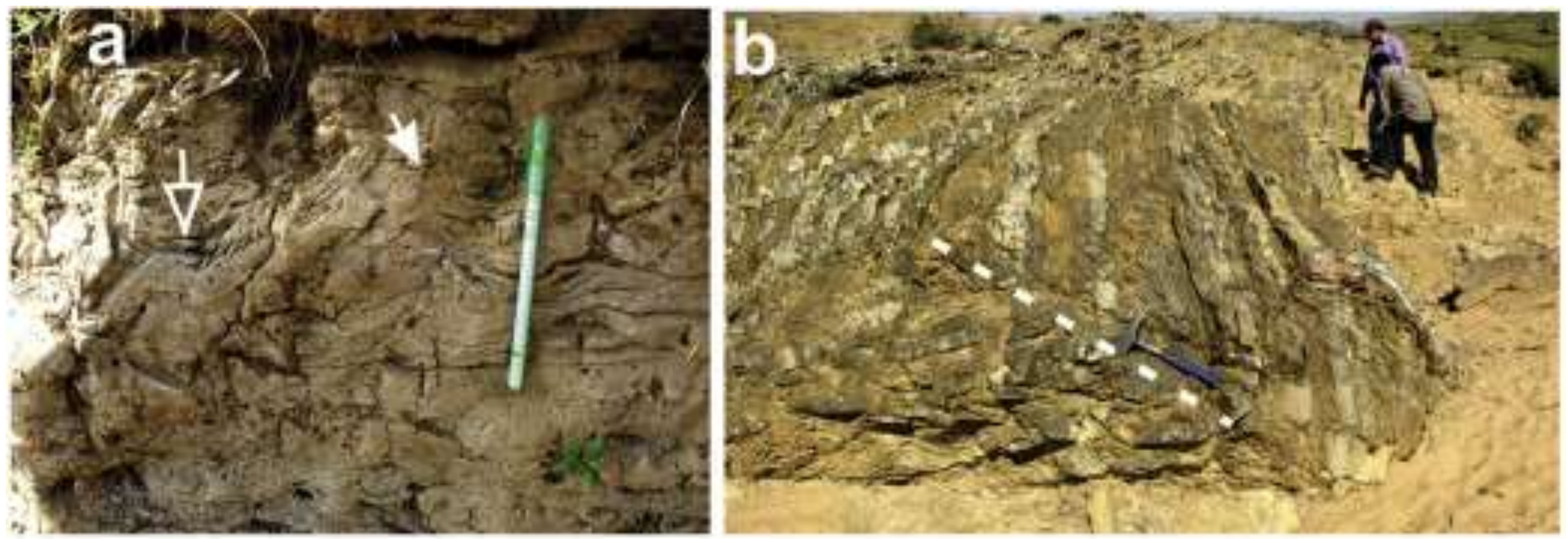

Fig. 7. Soft sediment deformation structures within the basal part of facies E: Convolute lamination and associated water escape structures (arrow). Pen length $15 \mathrm{~cm}$ (a) and large scale slump fold. Note trace of axial plane marked by dotted line (b). 
extensive soft sediment deformation structures are distributed in the lower stratigraphic horizon within this facies association (Sarkar et al., 1995). The soft sediment deformation structures include loading, convolute lamination, water escape structures, and large scale slide/slump folding (Figs. 7a, b).

This association sharply or erosively overlies facies association I and includes two facies.

\subsubsection{Facies E: Heterolithic bodies interbedded with fine sandstone}

Description: This facies is composed mainly of heterolithic bodies, comprising fine sandstonesiltstone interbeds with profuse wave ripples on their bed surfaces (Fig. 8a). The sandstone units are tabular or trough cross-stratified and the siltstone layers are planar laminated or ripplelaminated (Fig. 8b). Some intervening fine-grained tabular sandstone units also occur and mostly have sharp lower contacts and gradational or diffuse upper contacts. Internally most of these intervening sandstone units are swaley to hummocky cross-stratified with sole features (Figs. 8c, d); some of the sandstone beds are massive or planar laminated at the base and ripple laminated at the top (Fig. 8e). These sandstones are relatively fine-grained and are classified petrographically as quartz arenites.

\subsubsection{Facies F: Fine sandstone with minor siltstone, interbedded with tabular amalgamated coarse sandstone}

Description: This facies is composed mostly of fine-grained sandstone with local siltstone, with a marked increase in sandstone : siltstone ratios compared to facies E. This facies is gradationally associated with facies $\mathrm{E}$ with the proportion of facies $\mathrm{F}$ gradually increasing towards the top of the succession. The facies $\mathrm{F}$ sandstone units are planar laminated to trough cross-stratified or ripple-laminated (Fig. 9a). The proportion of planar laminae gradually increases towards the top of the succession. The planar laminated bed surfaces often bear parting lineations. Wave ripples, desiccation cracks and wrinkle marks also characterize the bedding surfaces of these sandstones (Figs. 9b, c). This fine sandy succession is commonly interrupted at regular intervals by sharp based relatively coarse-grained sandstone with hummocky and swaley cross-strata internally 

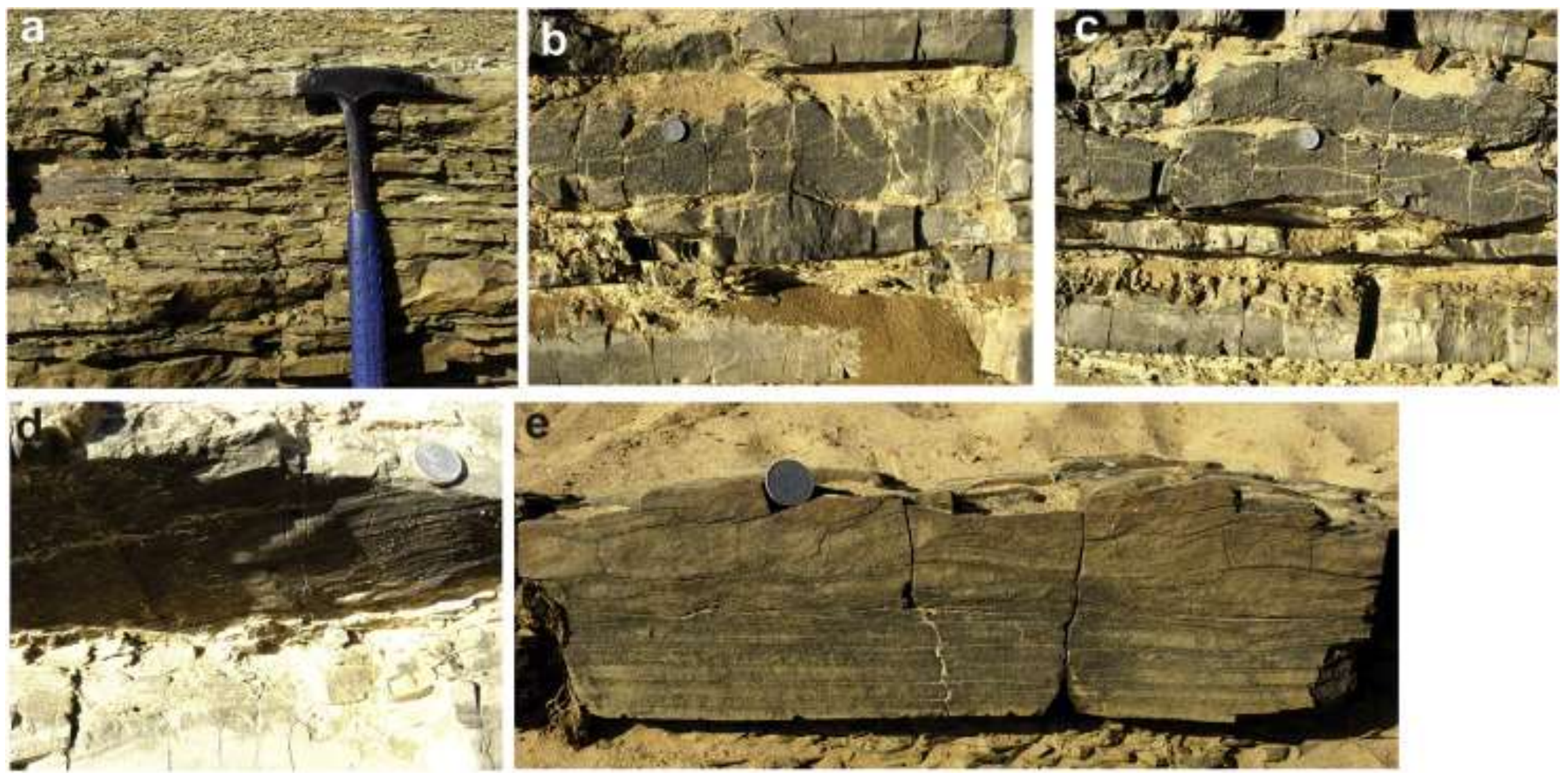

Fig. 8. Facies E composed of siltstone - sandstone interbeds (a). The fine-grained sandstone units have trough cross-strata. Coin diameter $1.5 \mathrm{~cm}$ (b). Swaley cross-strata within facies E. Coin diameter $1.5 \mathrm{~cm}$ (c). Flute cast at the base of hummocky cross-stratified sandstone. Coin diameter $1.5 \mathrm{~cm}(\mathrm{~d})$. Sandstone interbeds within facies $\mathrm{E}$ with planar laminae at the base and ripple laminated towards the top. Coin diameter 1.5 $\mathrm{cm}(\mathrm{e})$. 

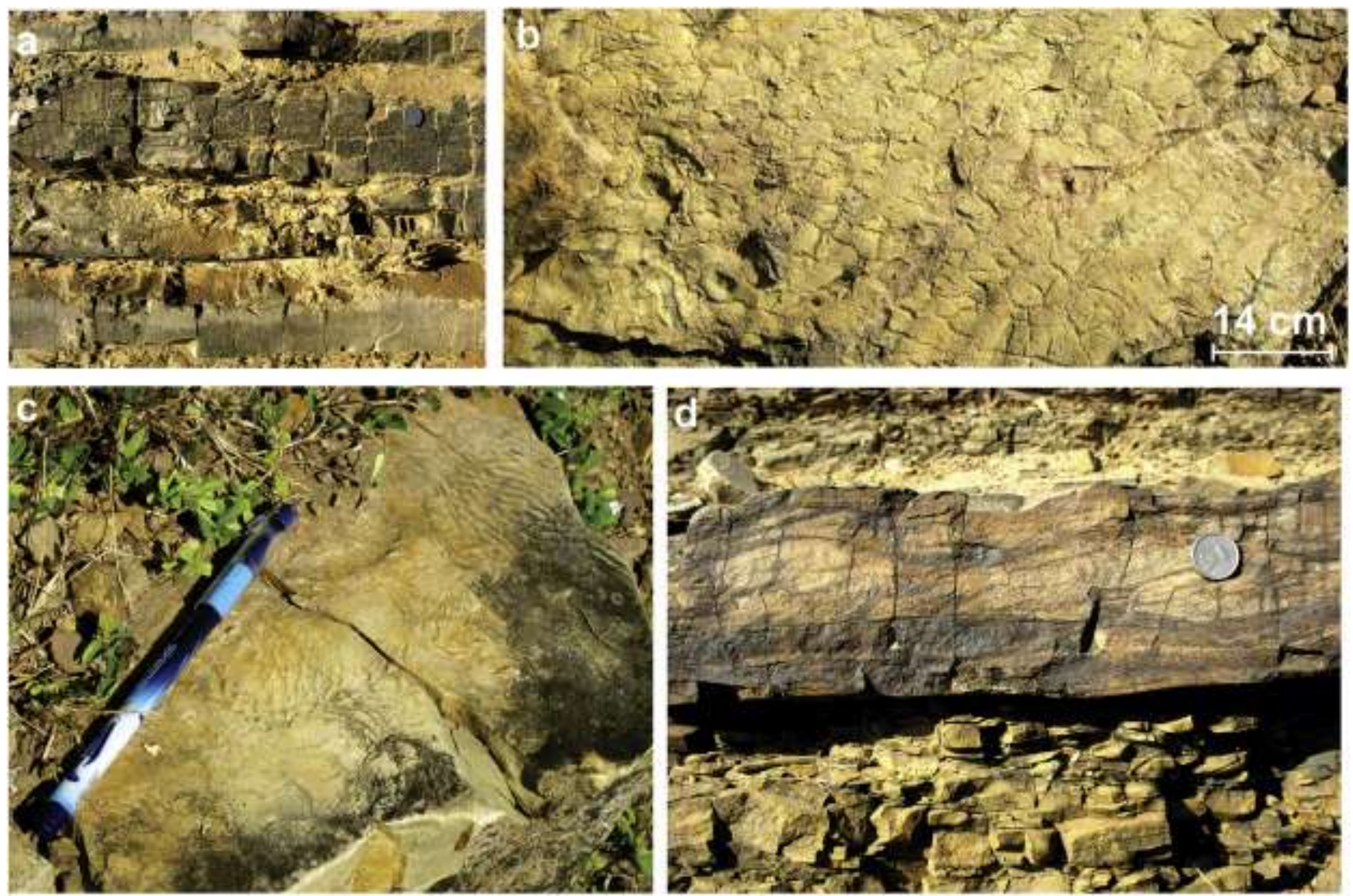

Fig. 9. Siltstone - sandstone alternations within facies F. The sandstone units are trough cross stratified. Coin diameter $1.5 \mathrm{~cm}$ (a). Microbial mat related structures within facies F: desiccation cracks. Pen length $15 \mathrm{~cm}$ (b). Wrinkle marks. Pen length $15 \mathrm{~cm}$ (c). Relatively coarse-grained hummocky cross-stratified sandstone often interspersed with facies F. Coin diameter $1.5 \mathrm{~cm}(\mathrm{~d})$. 
(Fig. 9d) and sole features at their bases. These coarser sandstones are laterally persistent and often amalgamate to form thick sandstone bodies not exceeding $1.2 \mathrm{~m}$ in thickness.

\subsubsection{Interpretation}

The heterolithic facies (facies E) with wave-generated features clearly suggests deposition above the fair-weather wave base. The tabular cross-bedded sandstone and wave/current rippled bed-tops suggest deposition in the middle to upper shoreface setting by storm events (cf., Dott and Bourgeois, 1982; Shirai and Tada, 2000). The interbedded heterolithic siltstone unis are interpreted as in situ fair-weather deposits reflecting lower energy interludes between storm events (Chakraborty et al., 2012a). The locally occurring intervening sharp based sandstones often bearing sole features and with hummocky cross-strata and/or massive to planar laminated character is inferred to be of storm origin (cf., Eriksson et al., 1998; Sarkar et al., 2002b). The wave rippled bed surfaces, trough cross-stratified to ripple-laminated fine sandstone beds within facies $\mathrm{F}$ indicate deposition in the middle to upper shoreface setting above the fair-weather wave base. The dominance of planar laminae with parting lineation towards the top of the succession clearly suggests deposition within a foreshore-beach environment (Sarkar et al., 2008). The frequent amalgamation of coarse sandstones, inferred as storm units with or without erosion, also corroborates the near-coastal condition of deposition of these units (Bose et al., 2001, 2012). The rectangular to polygonal desiccation cracks in non-cohesive sandstone owe their origin to microbial mats (cf., Noffke et al., 2001; Sarkar et al., 2008, 2014; Eriksson et al., 2010; Samanta et al., 2011, 2015). The wrinkles on sandstone bed-tops may have originated by gentle shear by waves or through currents acting on cohesive mat layers (Sarkar et al., 2008, 2014). The occurrence of mat-related desiccation cracks suggests subaerial exposure that is consistent with the interpretation of a foreshore-beach palaeogeography. The gradual coarsening and thickening upward trend clearly shows progradational character in this facies association also (Fig. 6).

\subsection{Facies association III:}

The facies association is deeply incised within facies associations II and I thereby demarcating an unconformity above the marine segment of the Koldaha Shale Member (Fig. 6). 


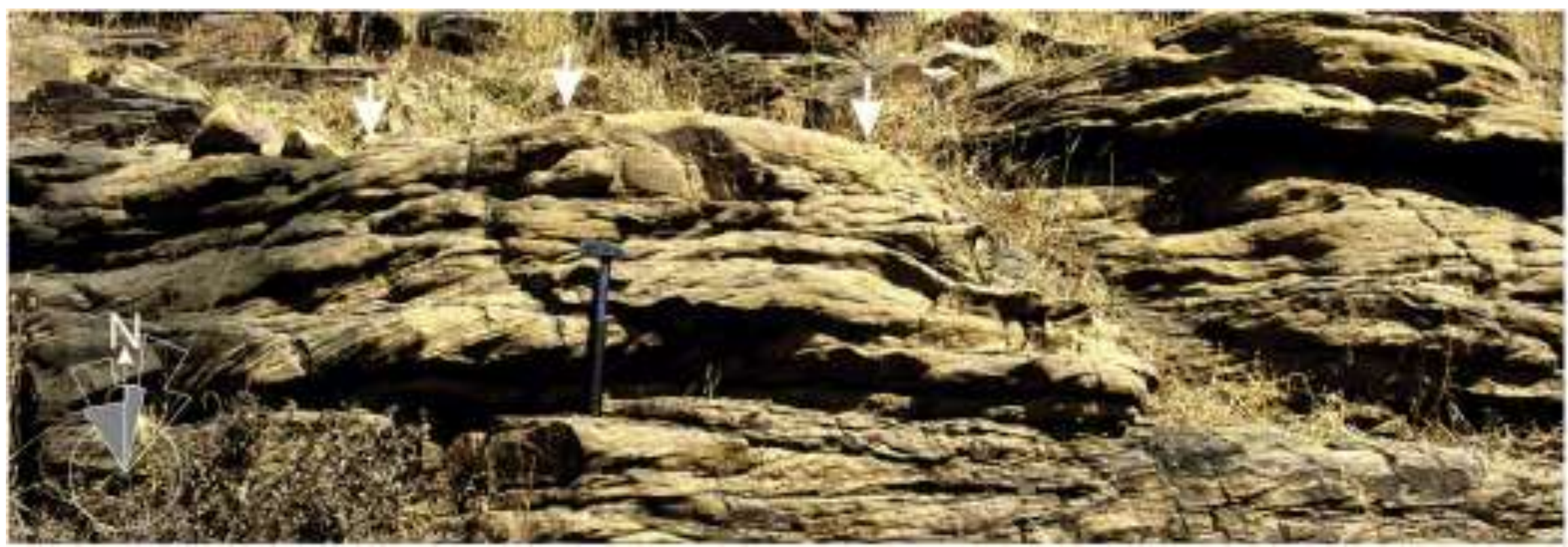

Fig. 10. Compound cross-stratified facies G. Note flat base and convex-upward top (arrows) of the macroform internally characterized by the compound cross-strata (DAE). Also note that the palaeocurrent roses of large (open) and small (solid) scale cross-strata are oriented in the same range of direction (a). 
This facies association is wedge-shaped and displays variable thicknesses across the study area. Facies association III is the coarsest of all the described associations. . The following facies constitute this facies association.

\subsubsection{Facies G: Compound cross-stratified sandstone}

Description: The facies is characterized by compound cross-strata (Fig. 10a). The large crossstrata dip at low angles, usually less than $10^{\circ}$, and both the large and small cross-strata are oriented in the same range of direction (Fig. 10a). Locally, pebbles define the top of the facies and are generally well rounded. This facies has a planar/erosional base and convex-up top and is associated with facies $\mathrm{H}$ described below (Fig. 10a). The facies is composed of very coarse- to medium-grained sandstone, often pebbly, ill-sorted and composed of sub-rounded to sub-angular grains.

\subsubsection{Facies $\mathrm{H}$ : Cosets of trough cross-stratified sandstone}

Description: This facies is relatively finer grained than facies $G$ and is composed of cosets of trough cross-strata (Fig. 11a). The trough cosets of this facies vary in thickness between $2.5 \mathrm{~m}$ and $10 \mathrm{~cm}$. The set thickness varies from $32 \mathrm{~cm}$ to $2.2 \mathrm{~cm}$. However, in the majority of occurrences cross-set thickness and grain size noticeably decrease upward within individual cosets (Fig. 11a). Preserved width : depth ratios of the troughs range between 6 and 10. The

foresets are generally pronouncedly normally graded within themselves. Facies $\mathrm{H}$ is composed of medium-grained, moderately sorted sub-lithic to lithic arenites.

\subsubsection{Facies I: Planar laminated sandstone}

Description: This facies comprises of coarse- to fine-grained, moderate to well sorted sandstone. This sandstone facies is devoid of pebbles, can be substantially thick up to about $50 \mathrm{~cm}$ (Fig. 12a) and is traceable laterally for up to $2 \mathrm{~m}$. Locally, this planar laminated facies occurs on top of facies H (Fig. 12a). These tabular laterally extensive and thick planar laminated sandstone units are sometimes found overlying the master erosion surfaces (Fig. 12b). 


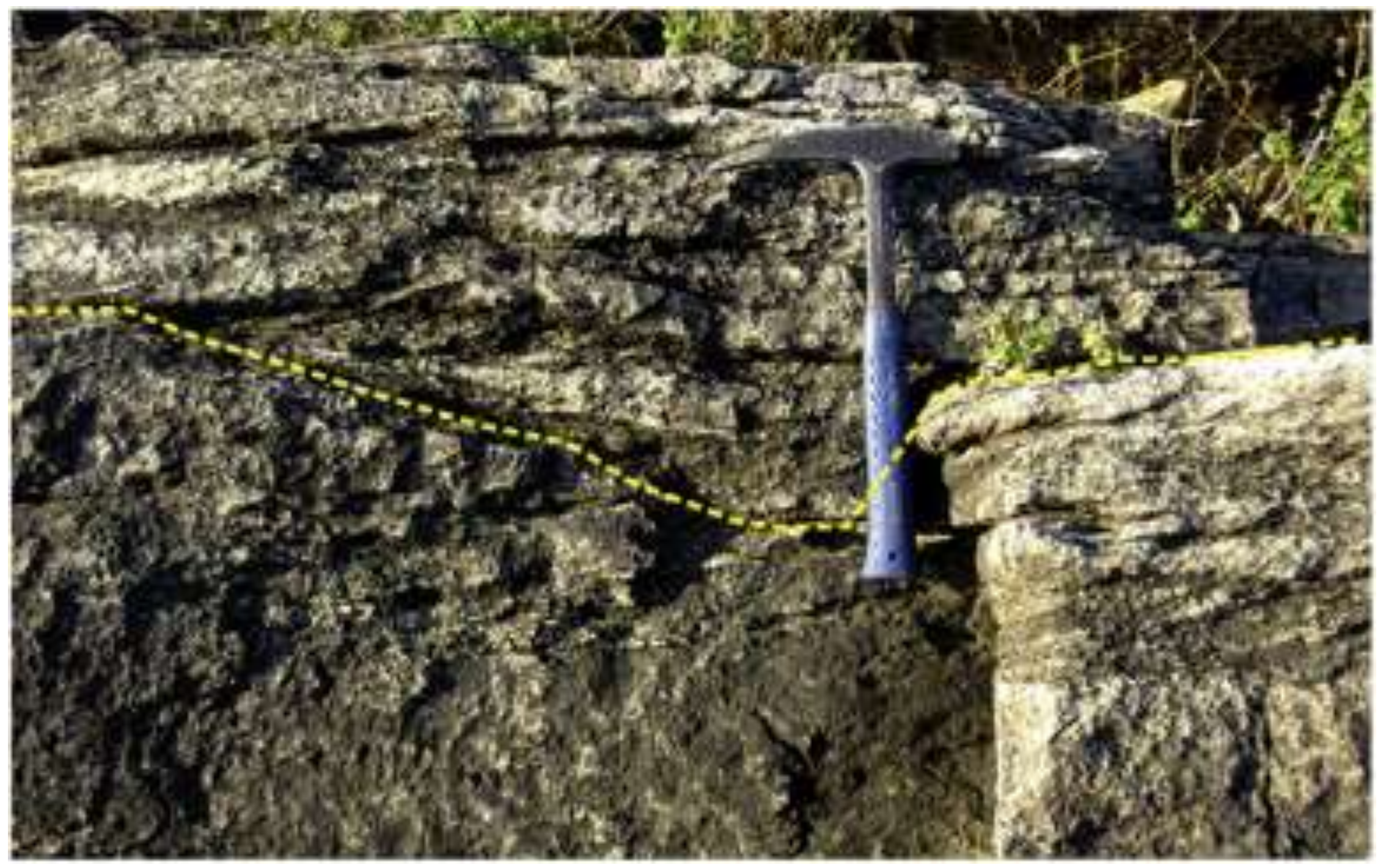

Fig. 11. Lenticular sandstone of facies $\mathrm{H}$ internally characterized by cosets of small-scale trough cross-strata (equivalent to small channel element). Note concave-upward base, often scoured (marked by dotted line) and flat top of the sandstone body (a). 

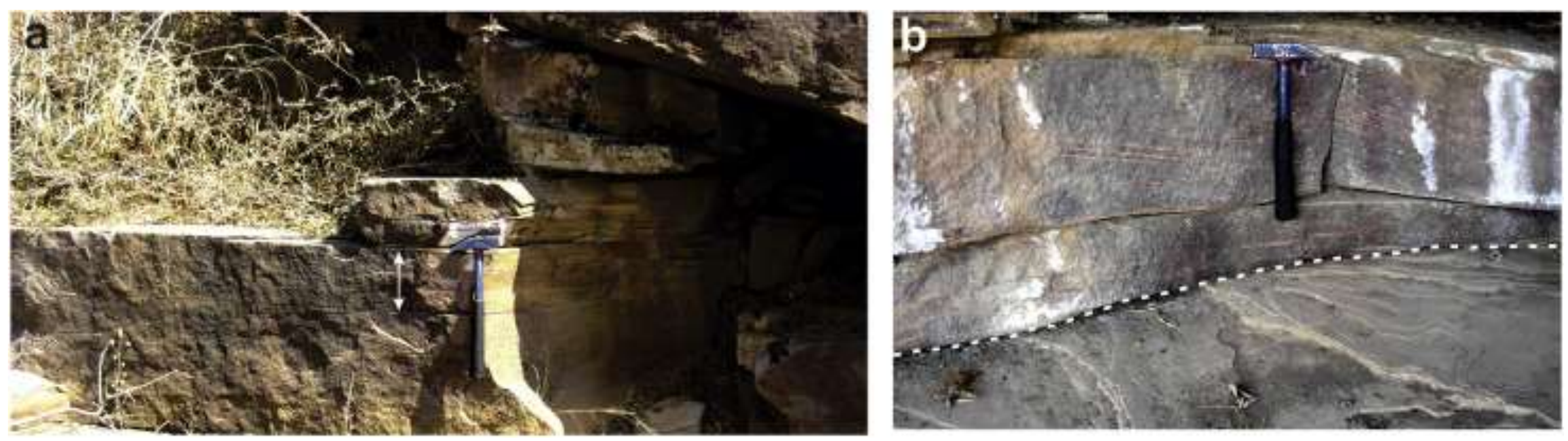

Fig. 12. Planar laminated medium- to fine-grained sandstone (marked by double-headed arrow) of facies I (equivalent to a type of sandsheet element). It rests over large trough cross-stratified sandstone units of facies $\mathrm{H}$ (representing small channel element) (a). Planar laminated relatively coarse-grained sandstone unit overlying master erosion surface (marked by dotted line) representing laminated sandsheet element (b). 


\subsubsection{Interpretation}

The coarse grain size, poor sorting and trough cross-strata of this facies association suggest its fluvial origin (Sarkar et al., 1996). Facies G is interpreted as having formed from bars on channel floors. Migrations of smaller bedforms across the crests and along the gentle downstream surfaces of the larger bedforms are inferred to have formed the small cross-strata (Sarkar et al., 2012). The pebble sheets on top of the sets are a possible product of high shear flow before emergence of the bedform, winnowing out the finer fractions. The facies $\mathrm{H}$ is most likely a product of dune migration along the channel floors at a high level of the lower flow regime (cf., Miall, 1985, 1988; Hadlari et al., 2006; Smith et al., 2006). In facies I sedimentation is interpreted to have taken place under high flow regime sheet flow conditions, particularly with reference to the sediment grain size (Bose et al., 2012).

\section{FLUVIAL ARCHITECTURAL ELEMENT}

Facies analysis may provide inferred depositional settings for fluvial deposits; however, change in facies characteristics along and across river channels is too frequent to be integrated in an evolutionary model. Moreover, in fluvial deposits, vertical successions are not generally correlatable between detached outcrops and cores (Miall, 1985). Similar litho-facies cycles may develop from both autocyclic as well as allocyclic processes (Miall, 1977, 1978; Nichols, 1999; Martinius et al., 2002). In comparison, study of a fluvial deposit in terms of geomorphic elements, designated as architectural elements, provides a more invariable picture, and a better understanding of the past fluvial systems and their evolution through time and space (for detailed discussion, see Miall, 1985). The term architectural element which can be defined as the macroform units that are larger than bedforms and smaller than channels (cf., Miall, 1985, 2006; Yu et al., 2002; Miall and Jones, 2003; Fielding, 2006; Bose et al., 2012; Sarkar et al., 2012), is essential to understand the fluvial channel pattern and its evolution through time (Miall, 1985; Sarkar et al., 2012). Hence, a combination of facies analysis and architectural element analysis offers a far better and fairly comprehensive understanding of an ancient fluvial system and its evolution through time (Miall, 1988; Miall and Jones, 2003; Bose et al., 2008; Sarkar et al., 
Table 1. Description and interpretation of architectural elements identified within the fluvial interval of the Koldaha Shale.

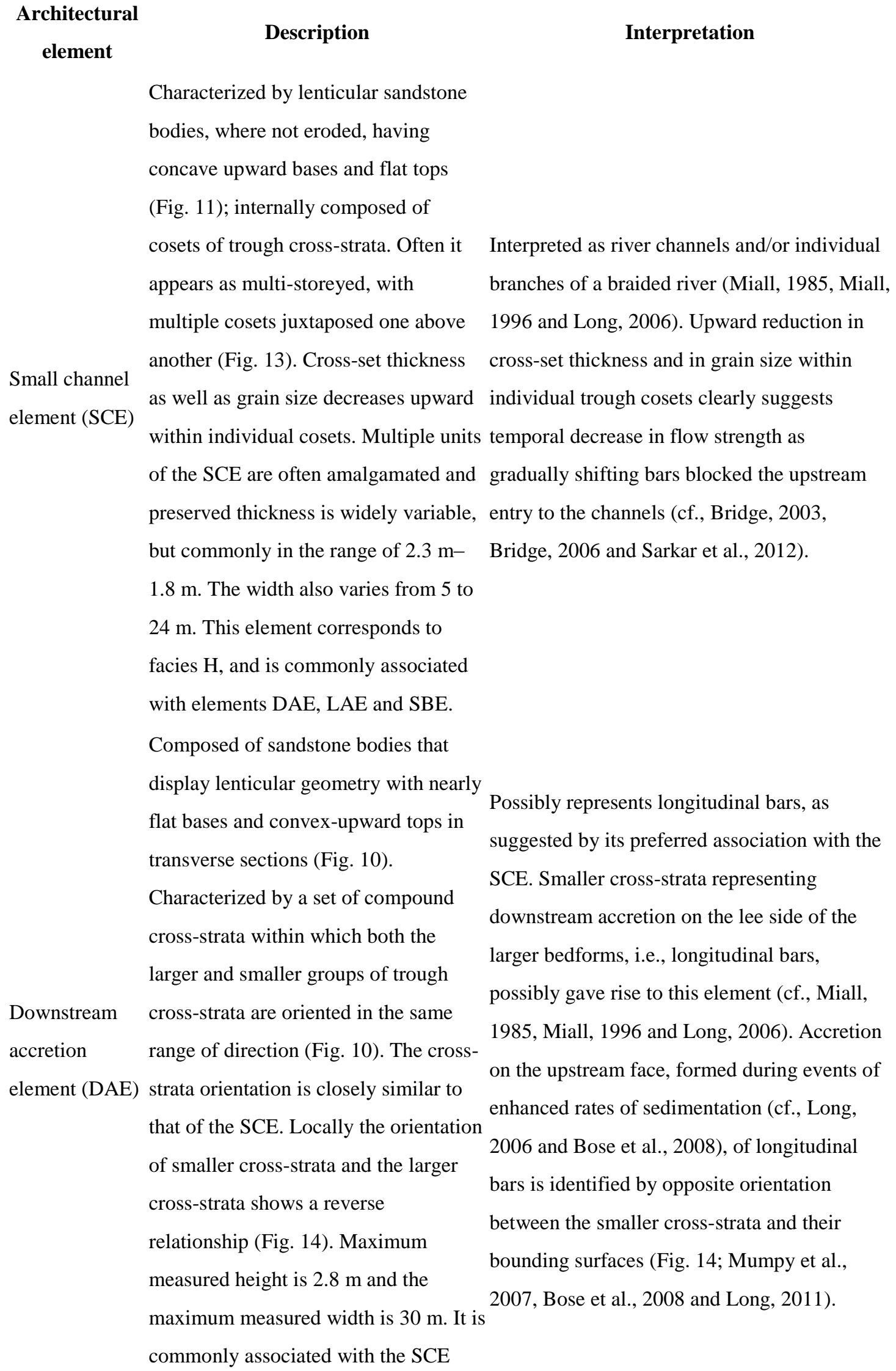




\section{Architectural}

element

Laminated

sandsheet

element (LSE)

and locally with the SBE, and it

corresponds to facies $\mathrm{G}$.

Characterized by coarse- or fine-

grained sandstone bodies, tabular,

sheet-like or wedge-like in geometry, The coarse-grained units overlying major

10-34 cm thick and laterally traceable erosion surfaces possibly represent cross-

beyond $2 \mathrm{~m}$. The bodies are internally channel bars or linguoid bars (cf., Allen, 1968,

planar laminated and commonly

Collinson, 1970 and Collinson, 1978). The

associated with the SCE. Ripples

medium-grained units immediately underlying

locally constitute the internal structure major erosion surfaces indicate sediments that

of this element and mostly are found settled out during high water stage, and were

towards the top of the planar laminated then reworked during low water stage (Sarkar

units. A coarse-grained variety often et al., 2012). Upward transitions from trough

rests on major erosional surfaces and is cross-strata to upper flow regime planar

invariably overlain by SCE (Fig. 12b). laminae in channel-fill deposits suggests

Another medium grained variety enhancement of flow shear in ephemeral

commonly occurs below master condition of river channels (cf., Hassan, 2005,

erosion surfaces and typically overlies Long, 2006 and Sarkar et al., 2012).

DAE or SCE (Fig. 12a). This element, as a whole, corresponds to facies I.

Characterized by a variety of sandstone bodies and internal structures. Some elements are characterized by

The first variety represents rapid deposition

internally crudely trough cross-

internally crudely trough crossunder high velocity traction current, possibly

stratified sandstone bodies having convex-up geometry (Fig. 15a). during flash floods (Bose et al., 2012). The other type suggests migration of generally unitary bedforms (cf., Miall, 1985, Singh

Maximum measured thickness and et al., 1993, Batson and Gibling, 2002, Miall

Sandy bedform width of this element are $30 \mathrm{~cm}$ and and Jones, 2003 and Long, 2011), although

element (SBE) $3.4 \mathrm{~m}$ respectively. In other examples, their tops may have been reworked and they are internally constituted primarily thereby incorporated components of different by a solitary set of tabular or trough characters. The element manifests migration of cross-strata; cross-laminae as well as planar laminae atop them may be dunes, transverse bars or bank attached bars (cf., Smith, 1970, Olsen, 1988, Reading, 1996, integral to these examples (Fig. 15b). Best et al., 2003 and Labourdette and Jones, Distinct lenticular geometry with rapid 2007). lateral thickness variation makes them 


\section{Architectural}

element

different from the LSE. In direction

perpendicular to the cross-strata, the

greatest measured length of the

element is $5 \mathrm{~m}$ and in direction parallel,

up to $15 \mathrm{~m}$. This element has been

included within facies $\mathrm{H}$. 


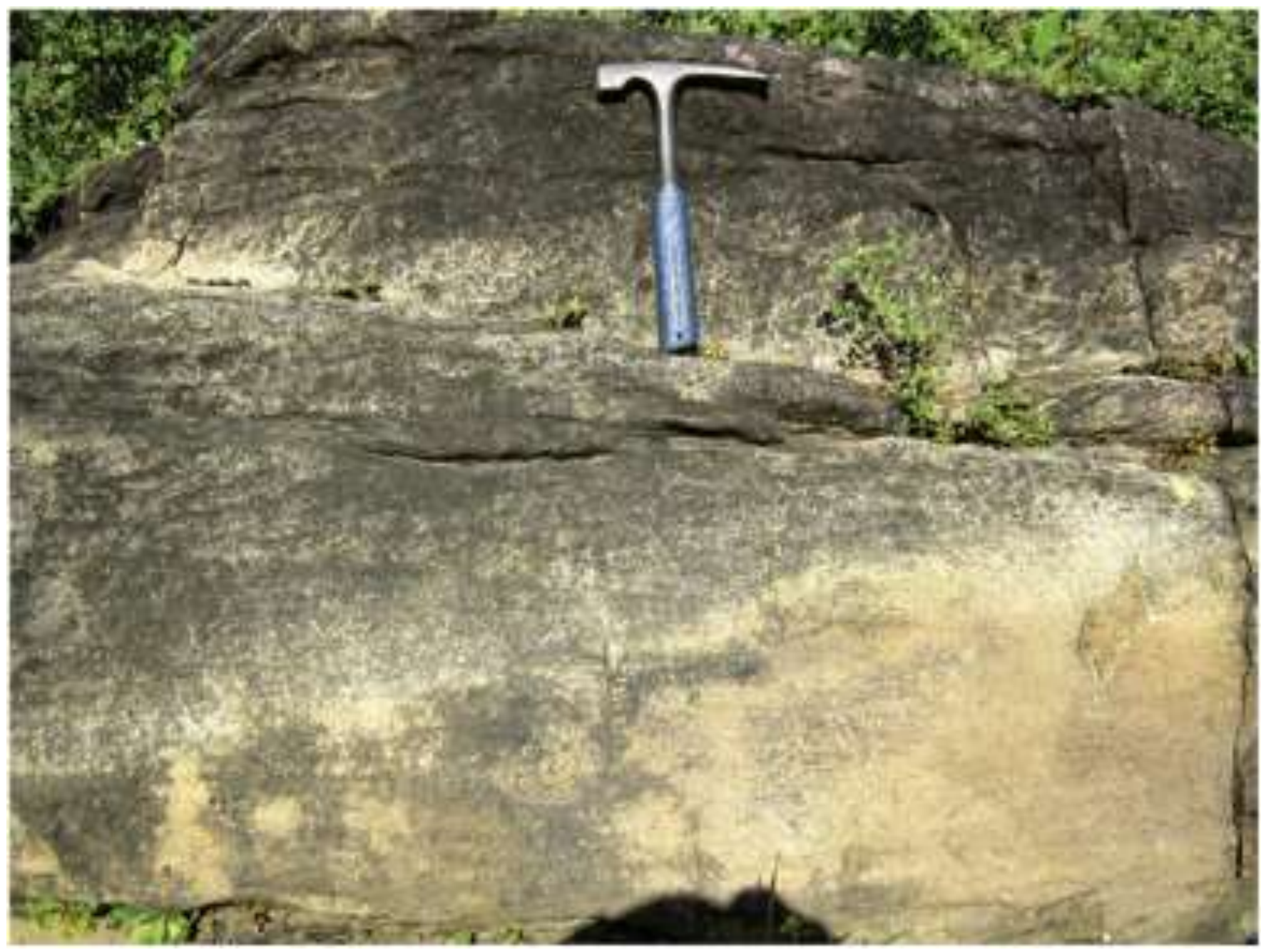

Fig. 13. Juxtaposed channel sandstone bodies stacked vertically one above another; the contact is marked by hammer 


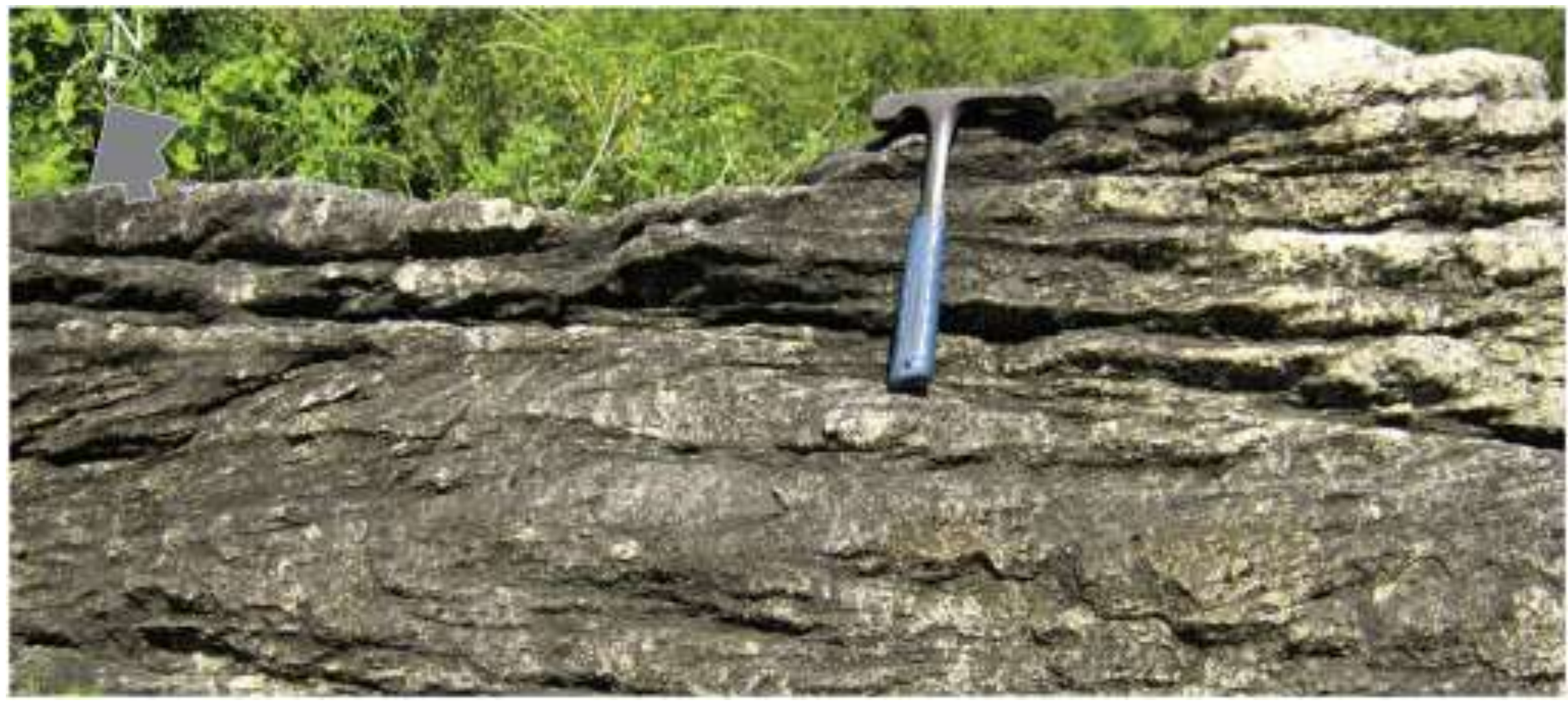

Fig. 14. Upstream accretion on inferred longitudinal bar. Note opposite inclinations of the larger cross-strata (solid rose) and smaller cross-strata (open rose). 


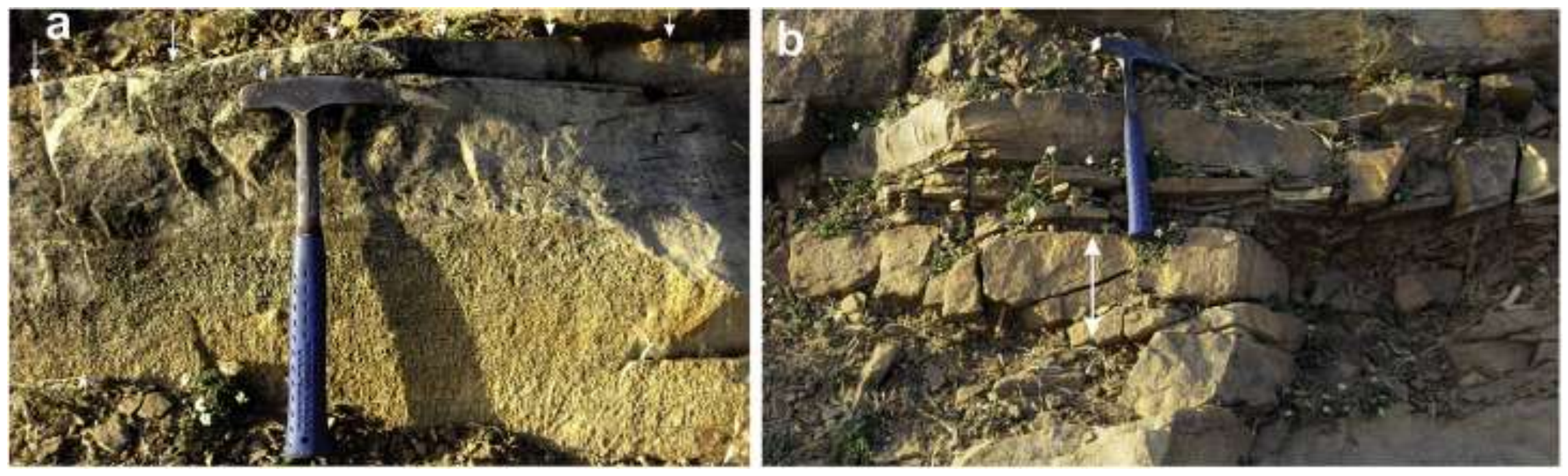

Fig. 15. Crudely cross-stratified sandstone bodies of sandy bedform element. Note convex-up geometry, marked by arrows, of the sandstone unit (a). Solitary set of trough cross-strata overlain by planar laminae characterize the sandy bedform element (b). 
2012). In the studied inferred fluvial litho-succession of the Koldaha Shale, fluvial architectural elements have been identified on the basis of lithology, internal structure and three-dimensional geometry of macroforms. The architectural elements have been described and interpreted in table 1.

\section{SEQUENCE ARCHITECTURE AND DISCUSSION}

The spatial and temporal variation in the identified facies records the sequence development in the Koldaha Shale of the study area, leading to recognition of three distinct sequence stratigraphic units, namely, highstand systems tract, forced regressive systems tract and lowstand systems tract (Figs. 6, 16). These units apparently responded to three positions along a curve of relative sea level change, which characteristically influenced the depositional environments and their temporal shift in the study area. It is generally accepted that the origin of sea-level fluctuations results from a combination of tectonic and eustatic processes (Vail et al., 1991); however, high-frequency, short-term variations in relative sea level are commonly interpreted to be essentially controlled by eustasy (Mitchum and Van Wagoner, 1991). The small-scale shallowing/shoaling upward cycles (parasequences) are interpreted to reflect global climate changes related to Milankovitch cycles (Fig. 6; e.g., Vail et al., 1991; Mitchum and Van Wagoner, 1991; Strasser et al., 1999). Parasequences may also be autocyclic in origin (Catuneanu et al., 2009; Zecchin and Catuneanu, 2013). However local and regional tectonic activity can also play a significant role in creation of accommodation space and hence in determining the stacking pattern. The term 'sequence' has been redefined by Catuneanu et al. (2011) as 'a cycle of change in accommodation or sediment supply'. Changes in accommodation are typically of allogenic origin (i.e., eustasy and tectonics, although additional space can also be created by compaction and sediment loading), whereas changes in sediment supply can be either of allogenic (e.g., climatic) or autogenic (e.g., fluvial channel avulsion, delta lobe switching and abandonment, efficiency of longshore sediment transport) origin (Catuneanu and Zecchin, 2013). The sequence stratigraphic architecture records the stratal stacking patterns, which is typically related to specific types of shoreline trajectory (Helland-Hansen and Hampson, 2009; Henriksen et al., 2009 and references therein). Forced regression is defined as downstepping at the shoreline, interpreted as the result of negative accommodation (Catuneanu et al., 2010). 
Sharp-based shoreface deposits overlying muddy shelf sediments are significant in view of their potential for hydrocarbon reservoirs (Zecchin and Catuneanu, 2015). The Koldaha shale is divided into three lithological units, inferred as the lowermost outer shelf shale unit, the middle sandy shoreface wedge unit and the upper coarse sandy braidplain unit (Fig. 16). The litho-succession records evidence of highstand, falling stage and lowstand systems tracts within the Koldaha Shale. In the marine unit, the outer shelf setting was the deepest part of the Koldaha shale palaeoenvironment (Facies A). Following deposition of the Kajrahat Formation (Fig. 1) the sea transgressed reaching up to at least outer shelf depths, records of which are confined to the lower part of the Koldaha Shale (Bose et al., 2001). The occurrence of black shales (Facies A) without any emergence features clearly suggests the deepest water deposits lying below the sandy litho-unit and the maximum marine flooding surface lies within them (Bose et al., 2001). However, the outer shelf succession is aggradational to slightly progradational within itself and the transition from facies $\mathrm{A}$ to facies $\mathrm{D}$ through facies $\mathrm{C}$ clearly shows a slightly coarseningupward succession representing a 'Highstand Systems Tract' (HST). The Koldaha sea possibly reached up to outer shelf conditions in this study area, however the shelf was most probably of low gradient as was common in other Proterozoic basins. Lack of occurrence of any mass flow products possibly supports this connotation. Existing models for sequence analysis for such Precambrian low gradient shelf settings consider the depositional sequences as composed either of transgressive and highstand deposits, or only superposed highstand deposits without any transgressive deposits (Sarkar et al., 2005; 2008) due to the omnipresent occurrence of microbial mats during that period (Sarkar et al., 2005, 2008, 2014; Samanta, 2009; Samanta et al., 2015). Lowstand and forced regressive deposits are typically restricted or absent in such settings (Baum and Vail, 1988; Chakraborty and Paul, 2008). The rarity in identification of falling stage systems tracts always causes an incomplete stratigraphic record, only representing half of a sea level cycle (Chakraborty and Paul, 2008).

The studied stratigraphic section of the Koldaha Shale records progradational shorefacebeach lithosomes above the distal shelf shale, with a basal erosional contact, known as regressive surface of marine erosion (RSME) (Fig. 16; cf. Zecchin and Catuneanu, 2013). This progradation clearly suggests rapid basinward migration of the shoreline with relative fall in sea level. The soft sediment deformation structures at the base of shallow water sediments are very common on the shelf edge and are directly related to its gravitational instability (Jones et al., 2015). 


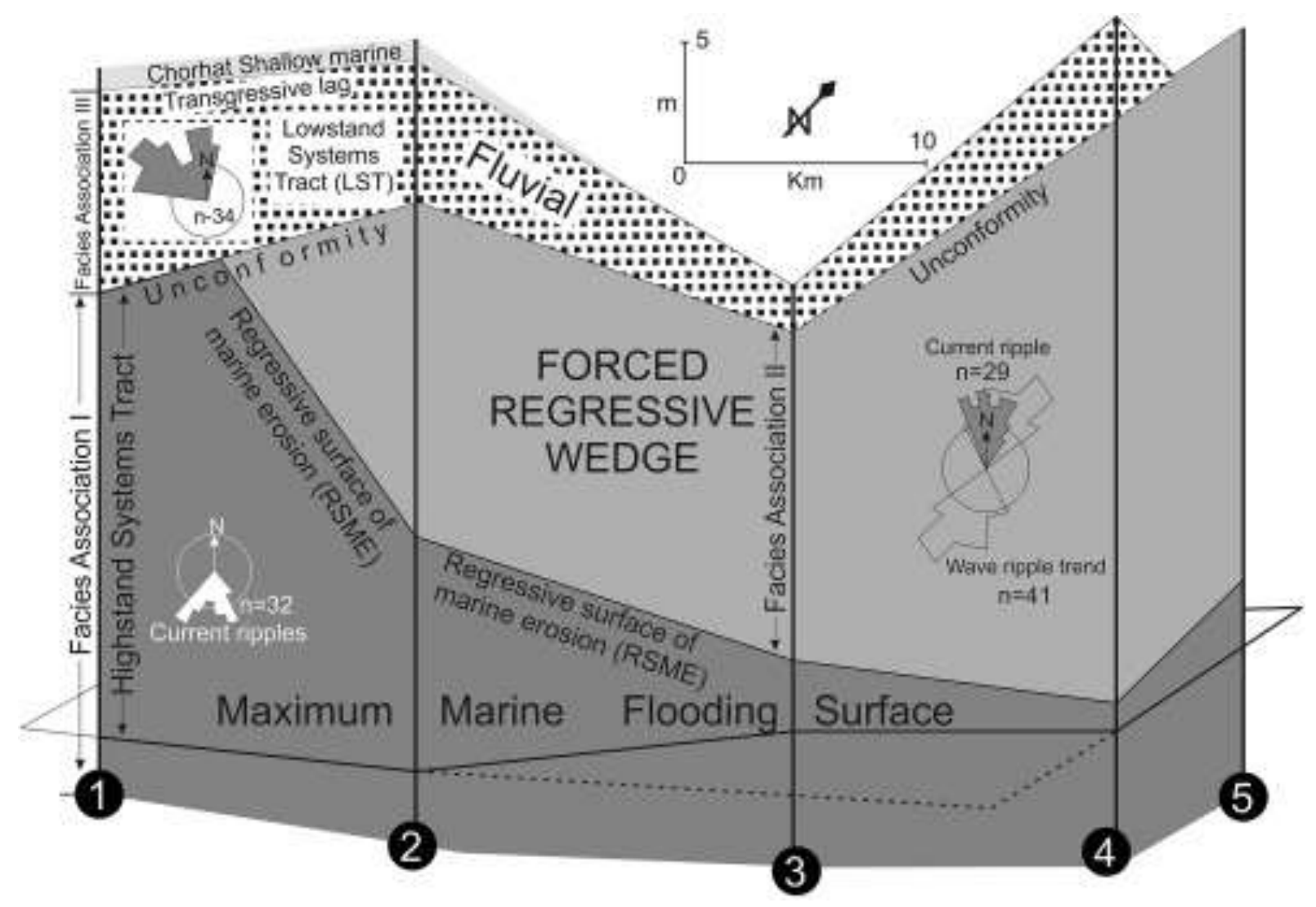

Fig. 16. Fence diagram based on correlation of facies associations, across the study area of the Koldaha Shale Member, is reconstructed from litho-successions shown in fig. 6, correlating a number of vertical sections, using maximum marine flooding surface as horizontal surface. Facies association I is aggradational to slightly progradational and bounded by the maximum marine flooding surface at the base and RSME (regressive surface of marine erosion) or its laterally coeval surface, the unconformity, at the top, representing the highstand systems tract (HST). Note that the facies association II (shoreface - beach) is wedge shaped with erosional basal contact, RSME, and downsteps from SW to NE directions. The wedge is unconformably overlain by fluvial braidplain deposits that in turn are overlain by the shallow marine Chorhat Sandstone with a transgressive lag at the base, representing a lowstand systems tract. Palaeocurrents for each facies association are given. 
However, their laterally extensive occurrence and stratigraphic constraints in the present case may points towards a tectonic origin (cf. Bose et al., 1997). The basal contact of this shorefacebeach sandstone appears to be planar or erosional for individual sections, but by correlating all localities of this section above the maximum flooding surface, the erosional contact becomes more evident; the contact shows down-stepping along SW to NE directions (Fig. 16). Such down-stepping of the basal contact of the progradational shoreface-beach litho-unit clearly suggests progressive fall in sea level with a continuous reduction in accommodation space. Similar sharp-based shoreface-beach deposits may be formed locally by rapid progradation due to high sediment supply or by storms (Schlager, 1993). However, the regional occurrence of such progradational facies cycles and the development of a subaerial unconformity at the top, suggest a regional fall in relative sea level. As such, the wedge shaped, basinward down-stepping shoreface-beach deposit can be considered as a product of forced regression or a falling stage systems tract (cf., Posamentier et al., 1992; Handford and Loucks, 1993; Helland-Hansen and Martinsen, 1996 Catuneanu and Eriksson, 1999; Fitzsimmons and Johnson, 2000; Plint and Nummedal, 2000; Veiga et al., 2005).

The basal erosion surface (RSME) of the forced regressive wedge possibly formed by wave ravinement concomitant with seaward migration of the palaeo-shoreline and diminishing accommodation space from landward to seaward side, or may have been related to sediment bypass during forced regression (cf., Li et al., 2011). The palaeo-shoreline for the Koldaha Sea is established to have been east-west (Bose et al., 2001; Sarkar et al., 2002a, 2011) and the forced regressive wedge pinching out southwest-ward clearly suggests that shoreline recession was from southwest to northeast (cf., Chakraborty and Paul, 2008).

The fluvial interval (facies association III) of the Koldaha Shale has apparent lithologic distinctiveness from the lower two facies associations (I and II). The architectural elements and their makeup indicate a predominantly braided pattern within the fluvial system, similar to most of the Precambrian rivers (cf., Long, 2011; Sarkar et al., 2012). Evidence of bar-top reworking coupled with frequent occurrence of reactivation surfaces (Fig. 17) suggests common and intense flow fluctuations within the fluvial system. The transition of this fluvial unit over the marine unit with a sharp erosional contact clearly depicts a subaerial unconformity associated with a drop of the base level. In the absence of any independent evidence for climatic interpretation, however, the abundance of flashy flow characters, evidence for flow fluctuations, and proliferation of high 


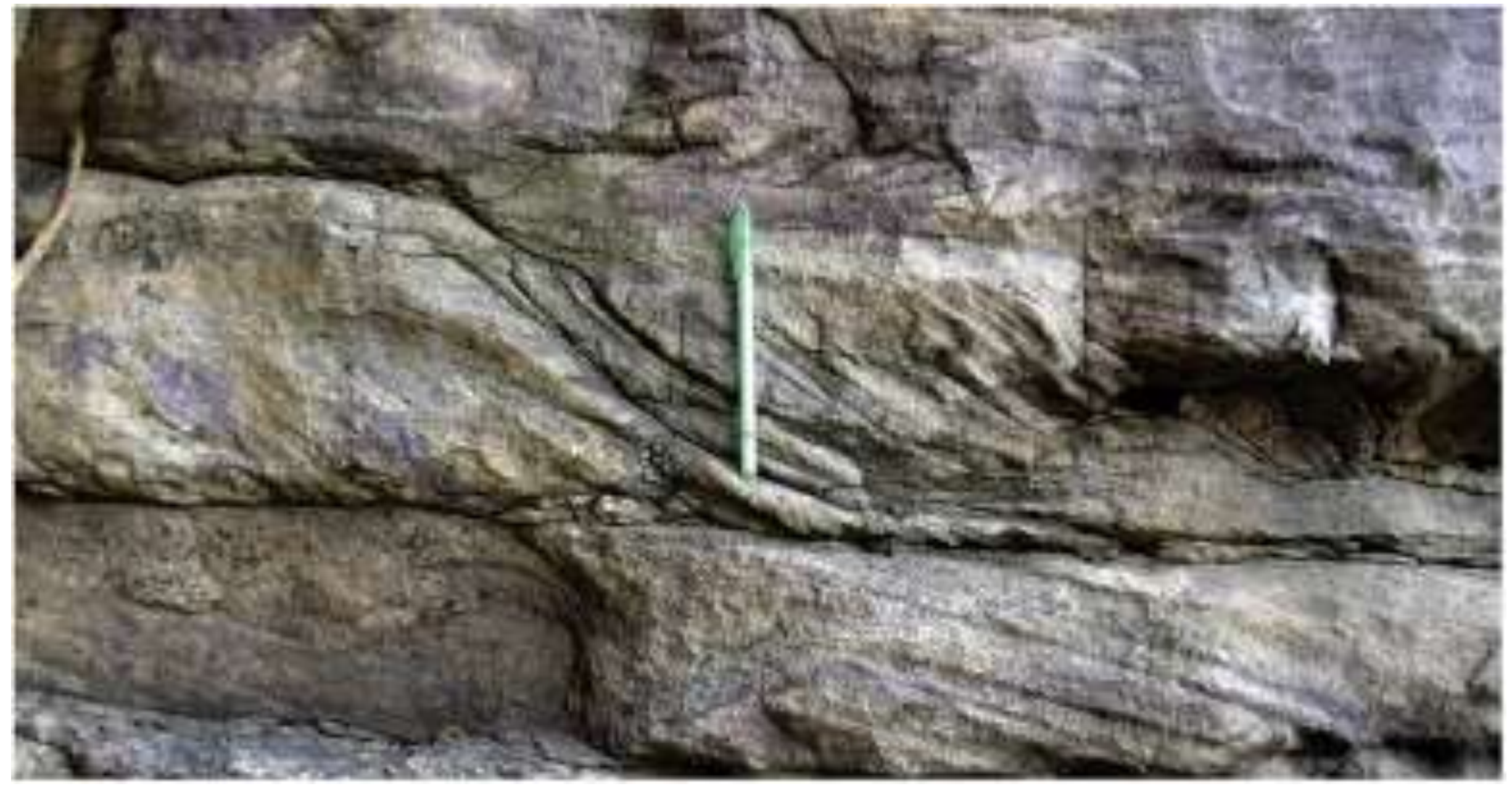

Fig. 17. Cross-sets are locally intercepted by broadly concave-up reactivation surfaces indicating flow fluctuation. Pen length $15 \mathrm{~cm}$. 
flow regime facies argue against a wet palaeoclimate. The overall fining upward trend of the fluvial interval suggests sediment aggradation during rise of the base level that followed the preceding fall. Nevertheless, frequent channel amalgamation within the fluvial unit suggests limited accommodation space conditions and a slow rise in relative sea level (Fig. 13). Limited availability of vertical accommodation space tends to lead to frequent avulsion of the river and the process appears to be exaggerated in the absence of vegetation (Catuneanu, 2006, 2009; Sarkar et al., 2012). A laterally extensive transgressive lag overlies the fluvial unit and the unconformity at the base identifies the unit as a sea level lowstand product (cf., Posamentier and Vail, 1988). The fluvial braidplain deposits thus clearly suggest a lowstand systems tract (Fig. 16).

Banerjee and Jeevankumar (2005) documented two highstand systems tracts (HSTs) within the Koldaha Shale without any transgressive systems tract in between. They reported a wide variety of microbial mat features from the unit and suggested that the occurrence of two HSTs was due to the influence of microbial mats (cf., Sarkar et al., 2005, 2008, 2014; Eriksson et al., 2010). Their study area possibly represents a more seaward part where a gradual transition from outer shelf to shoreface had taken place. Fluvial downcutting of the shelf is quite common for forced regression (Posamentier and Morris, 2000) and indications of this are evident towards the landward part of the basin. Thus the two erosion surfaces, i.e., at the top and the base of the forced regressive wedge, are coeval and they eventually merge together towards the landward side. A rise in relative sea level occurred following the unconformity that caused aggradation of the fluvial braidplain deposits (cf., Bose et al., 2012; Sarkar et al., 2012). Marine incursion again prevailed with continuing transgression and development of a shallow marine shelf environment (Chorhat Sandstone) accumulated sediments in the depositional site with a transgressive lag at the base (Sarkar et al., 2006). The preservation of the lowstand systems tract was possibly due to weakening of ravinement energy with continued transgression in a low gradient epeiric sea setting, as inferred commonly for the Precambrians (Catuneanu, 2002). Thus the study area records three regressive systems tracts: highstand normal, forced and lowstand normal. Abundant occurrence of microbial mat features within this Koldaha Shale has been described elsewhere (e.g., Banerjee and Jeevankumar, 2005; Schieber et al., 2007) with few examples having been shown here. Prolific growth of microbial mat on sediment surfaces causes severe impedance of either erosion or sediment reworking and thereby increases net sedimentation rate (Sarkar et al., 
2005, 2006, 2008; Samanta et al., 2015). Thus, microbial mat may act as a facilitator for preservation of these regressive products and may also have facilitated rapid progradation within this low gradient epeiric basin (cf. Chakraborty et al., 2012b). In view of the high organic carbon content within the Koldaha shale (facies A; Banerjee, 2000) the forced regressive wedge bears good economic importance for its possible hydrocarbon potential (Zecchin and Catunennu, 2015).

\section{CONCLUSIONS}

High resolution sequence stratigraphic analysis of the Koldaha Shale of the Lower Vindhyan suggests that the changes in facies pattern were concomitant with sea level changes. Three facies associations have been recognized, viz., shelf, shoreface-foreshore-beach and fluvial braidplain. The facies analysis unravels the depositional setting as having varied from outer shelf below wave base to foreshore-beach in the marine realm. The aggradational to slightly progradational outer shelf deposits overlying the maximum marine flooding surface and underlying the shoreface-beach deposits represent a highstand systems tract. The shoreface wedge overlies the outer shelf with sharp, often erosional contact, thus clearly suggesting rapid fall in relative sea level. Nevertheless, there was basinward shift of the shoreface wedge, as shown when correlating the palaeobathymetry across the study area and equating the palaeodepositional marker horizon (such as top of MFZ, Maximum Flooding Zone/MFS). The basal erosional surface of the shoreface wedge can thus be termed a "regressive surface of marine erosion" (RSME). The top of the shoreface wedge is incised by fluvial channels which deposited fluvial braidplain sediments. The subaerial unconformity clearly demarcates the sequence boundary. The shoreface wedge is absent landward and the fluvial braidplain deposits directly overlie the outer shelf sediments of the Koldaha Shale. Thus, the two erosion surfaces at the base, i.e. RSME, and top, i.e. subaerial unconformity, of the shoreface wedge were coeval, defining the maximum limit of marine and subaerial erosion, respectively. The sharply or erosionally overlying shoreface wedge with progradational stacking over the outer shelf represents the falling stage systems tract (FSST) or forced regressive systems tract (FRST). Following the unconformity, the sea level rose again and the aggradational thin braidplain 
deposits possibly record the short term early rise of sea level during lowstand, thereafter the study area again became inundated below the Chorhat sea.

Low sea floor gradient and lowered freeboard during formation of many of the Proterozoic intracratonic basins possibly rendered ideal conditions for development of forced regression during that time. However, the preservation potential of this forced regressive wedge is also very low due to the high erosion rate common during the Proterozoic. The rare record of forced regression may be due to lack of identification of such deposits due to their limited thickness or may be due to erosion by subsequent transgression. Microbial mat may have played a significant role in preserving this forced regressive wedge. Thus the stratal geometry of these Proterozoic basins may need to be re-examined and reassessed to redefine sequence stratigraphic architecture. In view of the hydrocarbon potential of these Proterozoic basins, these forced regressive wedges may provide high quality potential reservoirs.

Acknowledgements: The authors are greatly indebted to two anonymous reviewers for reviewing the manuscript on behalf of the Journal. They were highly benefited by advice received from Associate Editor Dr. M. Zecchin. PS gratefully acknowledges the financial support received from UGC minor project scheme. PS, SM and PGE acknowledge their respective Departments for infrastructural help.

\section{REFERENCES}

Aiello and Budillon, 2004. Lowstand prograding wedges as fourth-order glacio-eustatic cycles in the Pleistocene continental shelf of Apulia (southern Italy). SEPM Special Publication 81 , pp. $215-230$.

Ainsworth, R.B., Pattison, S.A.J., 1994. Where have all the lowstands gone? Evidence for attached lowstand system tracts in the western interior of North America. Geology 22, $415-418$.

Allen, J.R.L., 1968. Current Ripples. North-Holland Publishing Co, Amsterdam, p. 433. 
Amorosi, A., Colalongo, M.L., Fiorini, F., Fusco, F., Pasini, G., Vaiani, S.C., Sarti, G., 2004. Palaeogeographic and palaeoclimatic evolution of the Po Plain from 150-ky core records. Global and Planetary Change 40, 55 - 78.

Anderson, J.B., Fillon, R.H., 2004. Late Quaternary Stratigraphic Evolution of the Northern Gulf of Mexico Margin. SEPM Special Publication 79, pp. $1-23$.

Banerjee, S., 2000. Climatic versus tectonic control on storm cyclicity in Mesoproterozoic Koldaha Shale, central India. Gondwana Research 3, 521 - 528.

Banerjee, S., Jeevankumar, S., 2005. Microbially originated wrinkle structures on sandstones and their stratigraphic context: Paleoproterozoic Koldaha Shale, central India. Sedimentary Geology 176, $211-224$.

Batson, P.A., Gibling, M.R., 2002. Architecture of channel bodies and paleovalley fills in highfrequency Carboniferous sequences, Sydney Basin, Atlantic Canada. Bulletin Canadian Petroleum Geology 50(1), 138 - 157.

Baum, G.R., Vail, P.R., 1988. Sequence stratigraphic concepts applied to Paleogene outcrops, Gulf and Atlantic basins. In: Wilgus, C.K., Hastings, B.S., Kendall, C.G.St.C., Posamentier, H.W., Ross, C.A., Van Wagoner, J.C. (Eds.), Sea Level Changes-An Integrated Approach. SEPM Special Publication 42, pp. 309 - 327.

Berne', S., Lericolais, G., Marsset, T., Bourillet, J.F., De Bastist, M., 1998. Erosional offshore sand ridges and lowstand shorefaces: examples from tide- and wave-dominated environments of France. Journal of Sedimentary Research 68(4), 540 - 555.

Berne', S., Vagner, P., Guichard, F., Lericolais, G., Liu, Z., Yin, P., Trentesaux, A., Yi, H.I., 2002. Pleistocene forced-regressions and tidal sand ridges in the East China Sea. Marine Geology 188, 293 - 315. 
Best, J.L., Ashworth, P.J., Bristow, C.S., Roden, J., 2003. Three-Dimensional Sedimentary Architecture of a Large, Mid-Channel Sand Braid Bar, Jamuna River, Bangladesh. Journal of Sedimentary Research 73(4), 516 - 530.

Bose, P.K., Banerjee, S., Sarkar, S., 1997. Slope-controlled seismic deformation and tectonic framework of deposition of Koldaha Shale, India. Tectonophysics 269, $151-169$.

Bose, P.K., Eriksson, P.G., Sarkar, S., Wright, D.T., Samanta, P., Mukhopadhyay, S., Mandal, S., Banerjee, S., Altermann, W., 2012. Sedimentation patterns during the Precambrian: A unique record? Marine and Petroleum Geology 33(1), $34-68$.

Bose, P.K., Sarkar, S., Mukhopadhyay, S., Saha, B, Eriksson, P.G., 2008. Precambrian basinmargin fan deposits: Mesoproterozoic Bagalkot Group, India. Precambrian Research 162, $264-283$.

Bose, P.K., Sarkar, S., Chakraborty, S., Banerjee, S., 2001. Overview of the Meso- to Neoproterozoic evolution of the Vindhyan basin, central India. Sedimentary Geology 141(2), $395-419$.

Bridge, J.S., 2006. Fluvial facies models. In: Posamentier, H., Walker, R.G. (Eds.), Facies Models Revisited. SEPM, Special Publication 84, pp. 85 - 170.

Bridge, J.S., 2003. Rivers and Floodplains. Blackwell Scientific, Oxford, p. 504.

Cantalamessa, G. Di Celma, C., 2004. Sequence response to syndepositional regional uplift: insights from high-resolution sequence stratigraphy of late Early Pleistocene strata, Periadriatic Basin, central Italy. Sedimentary Geology, 164(3 - 4), 283 - 309.

Cantalamessa, G., Di Celma, C., Ragaini, L., 2006. Tectonic controls on sequence stacking pattern and along-strike architecture in the Pleistocene Mejillones Formation, northern 
Chile: Implications for sequence stratigraphic models. Sedimentary Geology, 183(1 - 2), $125-144$.

Catuneanu, O. and Zecchin, M., 2013. High-resolution sequence stratigraphy of clastic shelves II: Controls on sequence development. Marine and Petroleum Geology 39, 26 - 38.

Catuneanu, O., Galloway, W.E., Kendall, C.G.St.C., Miall, A.D., Posamentier, H.W., Strasser, A., Tucker, M.E., 2011. Sequence stratigraphy: methodology and nomenclature. Newsletters on Stratigraphy 44 (3), 173 - 245.

Catuneanu, O., Bhattacharya, J.P., Blum, M.D., Dalrymple, R.W., Eriksson, P.G., Fielding, C.R., Fisher, W.L., Galloway, W.E., Gianolla, P., Gibling, M.R., Giles, K.A., Holbrook, J.M., Jordan, R., Kendall, C.G.St.C., Macurda, B., Martinsen, O.J., Miall, A.D., Nummedal, D., Posamentier, H.W., Pratt, B.R., Shanley, K.W., Steel, R.J., Strasser, A., Tucker, M.E., 2010. Sequence stratigraphy: common ground after three decades of development. First Break 28, $21-34$.

Catuneanu, O., Abreu, V., Bhattacharya, J.P., Blum, M.D., Dalrymple, R.W., Eriksson, P.G., Fielding, C.R., Fisher, W.L., Galloway, W.E., Gibling, M.R., Giles, K.A., Holbrook, J.M., Jordan, R., Kendall, C.G.St.C., Macurda, B., Martinsen, O.J., Miall, A.D., Neal, J.E., Nummedal, D., Pomar, L., Posamentier, H.W., Pratt, B.R., Sarg, J.F., Shanley, K.W., Steel, R.J., Strasser, A., Tucker, M.E., Winker, C., 2009. Towards the standardization of sequence stratigraphy. Earth Science Review 92(1), 1 - 33.

Catuneanu, O., Eriksson, P.G., 1999. The sequence stratigraphic concept and the Precambrian rock record: an example from the $2.7-2.1 \mathrm{Ga}$ Transvaal Supergroup, Kaapvaal craton. Precambrian Research 97, 215 - 251.

Chakraborty, P.P., Das, P., Das, K., Saha, S., Balakrishnan, S., 2012a. Regressive depositional architecture on a Mesoproterozoic siliciclastic ramp: sequence stratigraphic and $\mathrm{Nd}$ 
isotopic evidences from Bhalukona Formation, Singhora Group, Chhattisgarh Supergroup, Central India. Precambrian Research 200 - 203, 129 - 148.

Chakraborty, P.P., Das, P., Saha, S., Das, K., Mishra, S.R., Paul, P., 2012b. Microbial mat related structures (MRS) from Mesoproterozoic Chhattisgarh and Khariarbasins, Central India and their bearing on shallow marine sedimentation. Episodes 35(4), $1-11$.

Chakraborty, P.P. and Paul, S., 2008. Forced regressive wedges on a Neoproterozoic siliciclastic shelf: Chandarpur Group, central India. Precambrian Research 162, 227 - 247.

Chakraborty, P.P., and Sarkar, S., 2005. Episodic emergence of offshore shale and its implications: Late Proterozoic Rewa Shale, Son valley, central India. Journal Geological Society of India 66, 699-712.

Chiocci, F.L., 2000. Depositional response to Quaternary fourthorder sea level fluctuations on the Latium margin (Tyrrhenian Sea, Italy). In: Hunt, D., Gawthorpe, R. (Eds.), Depositional Response to Forced Regression. Geological Society of London, Special Publication 172, pp. $271-289$.

Chiocci, F.L., Ercilla, G. and Torres, J., 1997. Stratal architecture of Western Mediterranean margins as the result of the stacking of Quaternary lowstand deposits below 'glacial eustatic fluctuation base-level'. Sedimentary Geology 112, 195 - 217.

Christe-Blick, N., Dyson, I.A., Von Der Borch, C.C., 1995. Sequence Stratigraphy and the interpretation of Neoproterozoic earth history. Precambrian Research 73, 3-26.

Collinson, J.D., 1978. Vertical sequence and sand body shape in alluvial sequences. Canadian Society of Petroleum Geologist, Memoir 5, 577 - 586.

Collinson, J.D., 1970. Bedforms of the Tana River, Norway. Geographical Annual 52A, 31 - 55. 
Davis, H.R., Byers, C.W., Pratt, L., 1989. Deposition, mechanism and organic matter in Mowry shale (Cretaceous) Wyoming. AAPG Bulletin 73, 1103 - 1116.

Dott, R.H.Jr., and Bourgeois, J., 1982. Hummocky stratification: significance and its variable bedding sequences. Geological Society of America Bulletin 93, 663 - 680 .

Ercilla, G., Farra'n, M., Alonso, B., Diaz, J.I., 1994. Pleistocene progradational growth pattern of the northern Catalonia continental shelf (northwest Mediterranean). Geo-Marine Letter $14,264-271$.

Eriksson, P.G., S., Sarkar, Banerjee, S., Porada, H., Catuneanu, O., Bose, P.K., and Samanta, P., 2010. Palaeoenvironmental context of microbial mat related structures in siliciclastic rocks: Examples from Proterozoics of India and South Africa, In: Seckbach J., Oren, A. (Eds.) Microbial Mats: Modern and Ancient Microorganisms in Stratified Systems, Springer-Verlag, pp. $71-108$.

Eriksson, P.G., Bose, P.K., Catuneanu, O., Sarkar, S. and Banerjee, S., 2008. Precambrian clastic epeiric embayments: examples from South Africa and India, In: Holmden, C., Pratt, B.R. (Eds.), Dynamics of Epeiric Seas: Sedimentological, Paleontological and Geochemical Perspectives. Geological Association of Canada, Special Publication 48, pp. 119 - 136.

Eriksson, P.G., Altermann, W., Eberhardt, L., Arend-herdbrinck, S., Bumby, A.J., 2002. Paleoproterozoic epeiric sea paleoenvironment: the Silverton Formation (Pretoria Group, Transvaal Supergroup), South Africa. International Association of Sedimentologists, Special Publication 33, pp. $351-367$.

Eriksson, P.G., Reczko, B.F.F., 1998. Contourites associated with pelagic mudrocks and distal delta fed turbidites in the Lower Proterozoic Timeball Hill Formation epeiric basin (Transvaal Supergroup), South Africa. Sedimentary Geology 120, 319 - 335. 
Field, M.E., Trincardi, F., 1992. Regressive coastal deposits on Quaternary continental shelves: preservation and legacy. In: Osborne, R.H., (Ed.), From Shoreline to Abyss: Contributions in Marine Geology in Honor of Francis Parker Shepard. SEPM, Special Publication 46, pp. $107-122$.

Fielding, C.R., 2006. Upper flow regime sheets, lenses and scour fills: Extending the range of architectural elements for fluvial sediment bodies. Sedimentary Geology 190, $227-240$.

Fitzsimmons, R., Johnson, S., 2000. Forced regressions: recognition, architecture and genesis in the Campanian of the Bighorn Basin, Wyoming. In: Hunt, D., Gawthorpe, R.L. (Eds.), Sedimentary Responses to Forced Regressions. Geological Society of London, Special Publication 172, pp. $113-140$.

Gensous, B., Tesson, M. 1996. Sequence stratigraphy, seismic profiles, and cores of Pleistocene deposits on the Rhone continental shelf. Sedimentary Geology 105, 183 - 190.

Gensous, B., Williamson, D., Tesson, M., 1993. Late Quaternary transgressive and highstand deposits on a deltaic shelf (Rhone delta, France), In: Posamentier, H.W., Summerhayes, C.P., Haq, B.U., Allen, G.P., (Eds.), Sequence Stratigraphy and Facies Associations: International Association of Sedimentologists, Special Publication 18, pp. $197-211$.

Gwenael, J., Serge, B., Marina, R., Maria-Angela, B., Bernier, P., Bernard, D., Sierro, F.J., Flores, J.A., Taviani, M., 2006. Shoreface migrations at the shelf edge and sealevel changes around the last glacial maximum (Gulf of Lions, NW Mediterranean). Marine Geology 234, $21-42$.

Hadlari, T., Rainbird, R.H, .Donaldson, J.A., 2006. Alluvial, eolian and lacustrine sedimentology of a Paleoproterozoic half-graben, Baker Lake Basin, Nunavut, Canada. Sedimentary Geology 190 (1-4), 47 - 70. 
Handford, C.R., Loucks, R.G., 1993. Carbonate depositional sequences and systems tracts response of carbonate platform to relative sea level changes. In: Loucks, R.G., Sarg, J.F. (Eds.), Carbonate Sequence Stratigraphy: Recent Development and Applications. AAPG Memoir 57, 3-41.

Hart, B.S., Long, B.F., 1996. Forced regression and lowstand deltas: Holocene Canadian examples. Journal of Sedimentary Research 66(4), 820 - 829.

Hassan, M.A., 2005. Characteristics of Gravel Bars in Ephemeral Streams. Journal of Sedimentary Research 75, $29-42$.

Haywick, D.W., 2000. Recognition and distinction of normal and forced regressions in cyclothermic strata: a Plio-Pleistocene case study from eastern North Island, New Zealand. In: Hunt, D., Gawthorpe, R. (Eds.), Depositional Response to Forced Regression. Geological Society of London, Special Publication 172, 193 - 215.

Helland-Hansen, W., Hampson, G.J., 2009. Trajectory analysis: concepts and applications. Basin Research, 21(5), $454-483$.

Helland-Hansen, W., Martinsen, O., 1996. Shoreline trajectories and sequences: description of variable deposition: a different perspective. Sedimentary Geology 92, $31-52$.

Henriksen, S., Hampson, G.J., Helland-Hansen, W., Johannessen, E.P., Steel, R.J., 2009. Shelf edge and shoreline trajectories, a dynamic approach to stratigraphic analysis. Basin Research, 21(5), 445 - 453.

Hunt, D., and Gawthorpe, R.L. (Eds.), 2000. Sedimentary response to forced regressions. Geological Society of London, Special Publication, p. 383.

Hunt, D., Tucker, M.E., 1992. Stranded parasequences and the forced regressive wedge systems tract: deposition during base level fall. Sedimentary Geology 81, $1-9$. 
Jones, G., Hodgson, D.M., Flint, S.S., 2015. Lateral variability in clinoform trajectory, process regime, and sediment dispersal patterns beyond the shelf-edge rollover in exhumed basin margin-scale clinothems. Basin Research, 27, $657-680$.

Labourdette, R., Jones, R.R., 2007. Characterization of fluvial architectural elements using a three-dimensional outcrop dataset: Escanilla braided system, South-Central Pyrenees, Spain. Geosphere 3(4), $422-434$.

Li, W., Bhattacharya, J. and Zhu, Y., 2011. Architecture of a forced regressive systems tract in the Turonian Ferron "Notom Delta”, southern Utah, U.S.A . Marine and Petroleum Geology 28, $1517-1529$.

Long, D.G.F., 2011. Architecture and depositional style of fluvial systems before land plants: a comparison of Precambrian, Early Palaeozoic, and modern river deposits. In: North, C. (Ed.), From River to Rock Record - The Preservation of Fluvial Sediments and their Subsequent Interpretation. SEPM Special Publication 97, pp. 37 - 61.

Long, D.G.F., 2006. Architecture of pre-vegetation sandy-braided perennial and ephemeral river deposits in the Paleoproterozoic Athabasca Group, northern Saskatchewan, Canada as indicators of Precambrian fluvial style. Sedimentary Geology 190(1-4), 71 - 95.

Martinius, A.W, Geel C.R, Arribas, J., 2002. Lithofacies characterization of fluvial sandstones from outcrop gamma-ray logs (Loranca Basin, Spain): the influence of provenance. Petroleum Geoscience, 8(1), $51-62$.

Massari, F., Sgavetti, M., Rio, D., D’Alessandro, A., Prosser, G., 1999. Composite sedimentary record of falling stages of Pleistocene glacio-eustatic cycles in a shelf setting (Crotone basin, south Italy). Sedimentary Geology 127, $85-110$.

Miall, A.D., 2006. Geology of fluvial deposits. Springer-Verlag, p. 582. 
Miall, A.D., 1996. The geology of fluvial deposits: sedimentary facies, basin analysis and petroleum geology. Berlin, Springer-Verlag, p. 582.

Miall AD., 1988. Reservoir heterogeneities in fluvial sandstone lessons from outcrop studies. American Association of Petroleum Geologist Bulletin 72, 682 - 697.

Miall AD., 1985. Architectural element analysis: a new method of facies analysis applied to fluvial deposits. Earth Science Review 22, 261 - 308.

Miall, A.D., 1978. Lithofacies types and vertical profile models in braided river deposits: a summery; In: Fluvial Sedimentology: Canadian Society of Petroleum Geology Memoir, $5,597-604$.

Miall, A.D., 1977. A review of the braided river depositional environment. Earth Science Review, 13, $1-62$.

Miall, A.D, Jones, B., 2003. Fluvial architecture of the Hawkesbury Sandstone (Triassic), near Sydney, Australia. Journal of Sedimentary Research 73, 531 - 45.

Mitchum, R.M.,Jr., Van Wagoner, J.C., 1991. High-frequency sequences and their stacking patterns: sequence stratigraphic evidence of high-frequency eustatic cycles. Sedimentary Geology $70,131-160$.

Morton, R.A., Suter, J.R., 1996. Sequence stratigraphy and composition of Late Quaternary shelf-margin deltas, northern Gulf of Mexico. AAPG Bulletin 80, 505 - 530.

Mumpy, A.J., Jol, H.M., Kean, W.F., Isbell, J.L., 2007. Architecture and sedimentology of an active braid bar in the Wisconsin River based on 3-D ground penetrating radar. GSA Special Papers 432, pp. 111-131. doi:10.1130/2007.2432(09). 
Naish, T., Kamp, P.J.J., 1997. Sequence stratigraphy of sixth-order (41 k.y. Pliocene-Pleistocene cylotherms, Wanganui basin, New Zealand: a case for the regressive systems tract. Geological Society of America Bulletin 109(8), 978 - 999.

Nichols, G., 1999. Sedimentology and Stratigraphy. Blackwell Science, p. 368.

Noffke, N., Gerdes, G., Klenke, T., Krumbein, W.E., 2001. Microbially induced sedimentary structures - A new category within the classification of Primary Sedimentary Structures. Journal of Sedimentary Research 71, $649-656$.

Okamura, Y., Blum, P., 1993. Seismic stratigraphy of Quaternary stacked depositional sequences in the Southwest Japan forearc: an example of fourth order sequences of an active margin. In: Posamentier, H.W., Summerhayes, C.P., Haq, B.U., and Allen, G.P., (Eds.), Sequence Stratigraphy and Facies Associations, International Association of Sedimentologists, Special Publication 18, pp. $213-232$.

Olsen, H., 1988. The architecture of a sandy braided-meandering river system: an example from the lower triassic Soiling Formation (M. Buntsandstein) in W-Germany. International Journal of Earth Science 77(3), $797-814$.

Olszewski, T.D., Patzkowsky, M.E., 2003. From cyclothems to sequences: the record of eustacy and climate on an icehouse epeiric platform (Pennsylvanian-Permian, North American mid-continent). Journal Sedimentary Research 73, 15 - 30.

Pattison, S.A.J., 2005. Storm-influenced prodelta turbidite complex in the lower Kenilworth Member at Hatch Mesa, Book Cliffs, Utah, U.S.A.: implications for shallow marine facies models: Journal of Sedimentary Research 75, 420 - 439.

Plint, A.G., 1988. Sharp-based shoreface sequences and 'offshore bars' in the Cardium Formation of Alberta: their relationship to relative changes in sea level. In: Wilgus, C.K., Hastings, B.S., Kendall, C.G.St.C., Posamentier, H.W., Ross, C.A., Van Wagoner, J.C. 
(Eds.), Sea Level Changes - An Integrated Approach. SEPM Special Publication 42, pp. $357-370$.

Plint, A.G., Nummedal, D., 2000. The falling stage systems tract: recognition and importance in sequence-stratigraphic analysis. In: Hunt, D., Gawthorpe, R. (Eds.), Depositional Response to Forced Regression. Geological Society of London, Special Publication 172, pp. $1-17$.

Pomar, L., Tropeano, M., 2001. The Calcarenite di Gravina Formation in Matera (southern Italy): new insights for coarse-grained, large-scale, cross-bedded bodies encased in offshore deposits. AAPG Bulletin 85(4), $661-689$.

Posamentier, H.W., Morris, 2000. Aspects of the stratal architecture of forced regressive deposits. In: Hunt, D., Gawthorpe, R.L. (Eds.), Sedimentary Responses to Forced Regressions. Geological Society of London, Special Publication 172, pp. 19 - 46.

Posamentier, H.W., G.P. Allen, 1999. Siliciclastic sequence stratigraphy: concepts and applications: SEPM Concepts in Sedimentology and Palaeontology 9, p. 210.

Posamentier, H.W., P.R. Vail, 1988. Eustatic controls on clastic deposition II - sequence and systems tract models. In: Wilgus, C.K., Hastings, B.S., Kendall, C.G.St.C., Posamentier, H.W., Ross, C.A. and van Wagoner, J.C. (Eds.), Sea level change - an integrated approach. SEPM Special Publication 42, pp. 125 - 154.

Posamentier, H.W., Allen, G.P., James, D.P., Tesson, M., 1992. Forced regressions in a sequence stratigraphic framework: concepts, examples and exploration significance. AAPG Bulletin 76, $1687-1709$.

Proust, J., Mahiux, G., Tessier, B., 2001. Field and seismic images of sharpbased shoreface deposits: implications for sequence stratigraphic analysis. Journal of Sedimentary Research 71, $944-957$. 
Rasmussen, B., Bose, P.K., Sarkar, S., Banerjee, S., Fletcher, I.R., Mc Naughton, N.J., 2002. 1.6 $\mathrm{Ga} \mathrm{U}-\mathrm{Pb}$ zircon ages for the Chorhat Sandstone, Lower Vindhyan, India: possible implication for early evolution of animals. Geology 30, 103 - 106.

Ray, J.S., Martin, M.W., Veizer, J., 2002. U-Pb zircon dating and Sr isotope systematics of the Vindhyan Supergroup, India. Geology 30, 131 - 134.

Reading, H.G. 1996. Sedimentary Environments: Processes, Facies and Stratigraphy. Blackwell Science, p. 688.

Ridente, D., Trincardi, F., 2005. Pleistocene bmuddyQ forced-regression deposits on the Adriatic shelf: A comparison with prodelta deposits of the late Holocene highstand mud wedge. Marine Geology 222 - 223, 213 - 233.

Rodero, J., Pallare`s, L., Maldonado, A., 1999. Late Quaternary seismic facies of the Gulf of Cadiz Spanish margin: depositional processes influenced by sea-level change and tectonic controls. Marine Geology 155, 131 - 156.

Saito, Y., 1991. Sequence stratigraphy on the shelf and the upper slope in response to the latest Pleistocene-Holocene sea level changes off Sendai, northeast Japan. In: McDonald, D.I.M., (Ed)., Sedimentation, Tectonics, and Eustasy: Sea-Level Changes at Active Margins. International Association of Sedimentologists, Special Publication 12, pp. 133 150.

Samanta, P., Mukhopadhyay, S., Sarkar, S. and Eriksson, P.G., 2015. Neoproterozoic substrate condition vis-à-vis microbial mat structure and its implications: Sonia Sandstone, Rajasthan, India. Journal of Asian Earth Science 106, 186 - 196. 
Samanta, P, Mukhopadhyay, S., Mandal, A., Sarkar, S., 2011. Microbial mat structures in profile: The Neoproterozoic Sonia Sandstone, Rajasthan, India. Journal of Asian Earth Sciences 40, $542-549$.

Samanta, P., 2009. Proterozoic siliciclastic sedimentation and sequence building: possible role of microbial mat: Sonia Sandstone, Rajasthan, India. Unpublished Ph.D. Thesis, Jadavpur University, India. p. 303.

Sarkar, S., Banerjee, S., Samanta, P, Chakraborty, N, Chakraborty, P.P., Mukhopadhyay’ S., and Singh, A.K., 2014. Microbial mat records in siliciclastic rocks: Examples from Four Indian Proterozoic basins and their modern equivalents in Gulf of Cambay. Journal of Asian Earth Science 91, 362 - 377.

Sarkar, S., Samanta, P., Mukhopadhyay, S., Bose, P.K., 2012. Stratigraphic architecture of the Sonia Fluvial interval, India in its Precambrian Context. Precambrian Research $214-215$, $210-226$.

Sarkar, S., Samanta, P. and Altermann, W., 2011. Setulfs, modern and ancient: Formative mechanism, preservation bias and paleoenvironmental implications. Sedimentary Geology 238(1-2), 71-78.

Sarkar, S., Bose, P.K., Samanta, P., Sengupta, P. and Eriksson., P.G., 2008. Microbial mat mediated structures in the Ediacaran Sonia Sandstone, Rajasthan, India, and their implications for Proterozoic sedimentation. Precambrian Research 162, 248 - 263.

Sarkar, S., Banerjee, S., Samanta, P. and Jeevankumar, S., 2006. Micrbial mat-induced sedimentary structures in siliciclastic sediments: examples from the $1.6 \mathrm{Ga}$ Chorhat Sandstone, Vindhyan Supergroup, M.P. India. Journal of Earth system Science 115(1), 49 -60 . 
Sarkar, S., Banerjee, S., Eriksson, P.G., Catuneanu, O., 2005. Microbial mat control on siliciclastic Precambrian sequence stratigraphic architecture: examples from India. Sedimentary Geology 176, $195-209$.

Sarkar, S., Chakraborty, S., Banerjee, S. and P.K. Bose, 2002a. Facies sequence and cryptic imprint of sag tectonics in late Proterozoic Sirbu Shale, central India. In: Altermann, W., Corcoran, P. (Eds.), Precambrian Sedimentary Environments: A Modern Approach to Ancient Depositional Systems. International Association of Sedimentologists, Special Publication 33, pp. $369-382$.

Sarkar, S., Banerjee, S., Chakraborty, S. and Bose, P.K., 2002b. Shelf storm flow dynamics: insight from the Mesoproterozoic Rampur Shale, central India. Sedimentary Geology $147,89-104$.

Sarkar, S., Banerjee, S. and Bose, P.K., 1996. Trace fossils in the Mesoproterozoic Koldaha Shale, Central India, and their implications. Neues Jahrbuch fur Geologie und Palaontologie-Monatshefte 7, $425-438$.

Sarkar, S., Banerjee, S. and Chakraborty, S., 1995. Synsedimentary seismic signatures in the Mesoproterozoic Koldaha Shale, Kheinjua Formation, central India. Indian Journal of Earth Sciences 22, $158-164$.

Schieber, J., Bose, P.K., Eriksson, P.G., Banerjee, S., Sarkar, S., Altermann, W., Catuneanu, O., (Eds.), 2007. Atlas of Microbial Mat Features Preserved Within the Siliciclastic Rock Record. Atlases in Geoscience 2, Elsevier, Amsterdam, pp. 117 - 133.

Schlager, W., 1993. Accommodation and supply—a dual control on stratigraphic sequences. In: Cloeting, S., Sassi, W., Horvath, F., Puigdefabregas, C. (Eds.), Basin Analysis and Dynamics of Sedimentary Basin Evolution. Sedimentary Geology 86, pp. 111 - 136. 
Serge, B., Gorini, C., 2005. The Gulf of Lions: an overview of recent studies within the French 'Margins' Programme. Marine and Petroleum Geology 22, 691 - 693.

Shirai, M., Tada, R., 2000. Sedimentary successions formed by fifth-order glacio-eustatic cycles in the middle to upper quarternary Formations of Oga Peninsula, Northeast Japan. Journal of Sedimentary Research 70(4), $839-849$.

Singh, A., Bhardwaj, B.D., Ahmad, A.H.M., 1993. Tectonic setting and sedimentology of Ganga River sediments, India. Boreas 22(1), $38-46$.

Smith, G.H.S., Best, J.L, Bristow, C.S., Petts, G.E., 2006. Braided Rivers: Process, Deposits, Ecology and Management. Nature, p. 396.

Smith, N.D., 1970. The braided stream depositional environment: comparison of the Platte River with some Silurian clastic rocks, North Central Appalachians. Geological Society of America Bulletin 81, 2993 - 3014.

Somoza, L., Hernandez-Molina, F.J., De Andres, J.R., 1997. Continental shelf architecture and sea-level cycles: Late Quaternary high-resolution sequence stratigraphy of the Gulf of Cadiz, Spain. Geo-Marine Letter 17, 133 - 139.

Srivastava, A.P., and Rajagopalan, G., 1988. F-T ages of Vindhyan Glauconitic sandstone beds exposed around Rewatbhata area, Rajasthan. Journal Geological Society of India 32, 527 -529 .

Strasser, A., Pittet, B., Hillgärtner, H., Pasquier, J.B., 1999. Depositional sequences in shallow carbonate-dominated sedimentary systems: concepts for a high-resolution analysis. Sedimentary Geology 128, $201-221$. 
Surlyk, F and Noe-Nygaard, N., 2005. A forced regressive shelf-margin wedge formed by transition - slope progradation: lowermost Cretaceous Rauk Plateau Member, Jameson Land, East Greenland. Geological Society of Denmark, Bulletin 52, 227 - 243.

Suter, J.R., Berryhill, H.L., and Penland, S., 1987. Late Quaternary sealevel fluctuations and depositional sequences, southwest Louisiana continental shelf. In: Nummedal, D., Pilkey, O.H., and Howard, J.D., (Eds.), Sea-Level Fluctuation and Coastal Evolution: SEPM, Special Publication 41, pp. $199-219$.

Suter, J.R., and Berryhill, H.L., 1985. Late Quaternary shelf margin deltas, northwest Gulf of Mexico. American Association of Petroleum Geologists, Bulletin 69, 77 - 91.

Sydow, J., Roberts, H.H., 1994. Stratigraphic framework of late Pleistocene shelf-edge delta, Northeast Gulf of Mexico. AAPG Bulletin 78 (8), 1276 - 1312.

Taylor, S.P., Sellwood, B.W., Gallois, R.W., Chambers, M.H., 2001. A sequence stratigraphy of the Kimmeridgian and Bolonian stages (late Jurassic) Wessex-Weald Basin, southern England. Journal Geological Society of London 158, $179-192$.

Tesson, M., Posamentier, H.W., Gensous, B., 2000. Stratigraphic organization of late Pleistocene deposits of the western part of the Golfe du Lion shelf (Languedoc shelf), western Mediterranean Sea, using high-resolution seismic and core data. AAPG Bulletin 84 (1), $119-150$.

Tesson, M., Allen, G.P., Ravenne, C., 1993. Late Pleistocene shelf perched lowstand wedges on the Rhone continental shelf. In: Posamentier, H.W., Summerhayes, C.P., Haq, B.U., Allen, G.P., (Eds.), Sequence Stratigraphy and Facies Associations. International Association of Sedimentologists, Special Publication 18, pp. $183-196$.

Tesson, M., Gensous, B., Allen, G.P., and Ravenne, C., 1990. Late Quaternary deltaic lowstand wedges on the Rhone continental shelf, France: Marine Geology 91, 325 - 332. 
Trincardi, F., Correggiari, A., 2000. Quaternary forced regression deposits in the Adriatic basin and the record of composite sea-level cycles. In: Hunt, D., Gawthorpe, R.L., (Eds.), sedimentary responses to forced regressions. Geological Society of London, Special Publication 172, pp. $245-269$.

Trincardi, F., Field, M.E., 1991. Geometry, lateral variation and preservation of downlapping regressive shelf deposits: Eastern Tyrrhenian sea margin, Italy. Journal of Sedimentary Petrology 61, $775-790$.

Vail, P.R., Audemard, F., Bowman, S.A., Eisner, P.N., Perez-Cruz, C., 1991. The stratigraphic signatures of tectonics, eustasy and sedimentology: an overview. In: Einsele, G., Ricken, W., Seilacher, A. (Eds.), Cycles and Events in Stratigraphy. Springer-Verlag, Berlin, pp. $617-659$.

Veiga, G.D., Howell, J.A., Strömbäck, A., 2005 (Eds.). Anatomy of a mixed marine - nonmarine lowstand wedge in a ramp setting. The record of a Barremian - Aptian complex relative sea-level fall in the central Neuque'n Basin, Argentina, In: Veiga, G.D., Howell, J.A., Strömbäck, A. (Eds.), The Neuque'n Basin, Argentina: A Case Study in Sequence Stratigraphy and Basin Dynamics, Geological Society, London, Special Publications 252, pp. $139-162$.

Walker, R.G. 1984. Facies models. Geological Association Canada, Newfoundland, Canada, p. 317.

Yu X., Ma X., Quing H., 2002. Sedimentology and reservoir characteristics of a Middle Jurassic fluvial system, Datong Basin, northern China. Bulletin Canadian Petroleum Geology $50(1), 105-117$.

Zecchin, M., Catuneanu, O., 2015. High-resolution sequence stratigraphy of clastic shelves III: Applications to reservoir geology. Marine and Petroleum Geology 62, $161-175$. 
Zecchin, M., Catuneanu O., 2013. High-resolution sequence stratigraphy of clastic shelves I: Units and bounding surfaces. Marine and Petroleum Geology 39, $1-25$.

Zecchin, M., Civile, D., Caffau, M., Sturiale, G., Roda, C., 2011. Sequence stratigraphy in the context of rapid regional uplift and high-amplitude glacio-eustatic changes: the Pleistocene Cutro Terrace (Calabria, southern Italy). Sedimentology 58, 442 - 477. 